\title{
DIGNIDADE E AUTONOMIA: A PONTE DOGMÁTICA PARA O TESTAMENTO VITAL
}

\section{Rogério Donnini ${ }^{1}$}

Raphael Abs Musa de Lemos ${ }^{2}$

\section{Resumo}

O presente artigo tem o objetivo de examinar o testamento vital como uma categoria negocial autônoma a partir dos princípios da dignidade da pessoa humana e da autonomia privada. Optou-se, para tanto, por metodologias dialética e dedutiva, confrontando-se, assim, o pensamento dos autores que se dedicaram ao tema e realizando-se inferências a partir das premissas gerais histórico-filosóficas traçadas nas primeiras seções do trabalho, com o complemento de algumas decisões judiciais. Desse modo, entende-se que o testamento vital tem natureza de negócio jurídico extrapatrimonial, unilateral e personalíssimo, com o objeto voltado ao disciplinamento de intervenções médicas em momento futuro, antecipando então o desejo ou a recusa do paciente de manter-se artificialmente vivo, ou de receber determinado tratamento. A forma deve ser livre, salvo futura disposição legal, e o agente deve gozar da capacidade de consentimento, implicando discernimento específico para o ato. Ao final, conclui-se pela necessidade de admitir-se a eutanásia em hipóteses estritamente definidas em lei, sem significar que a sua vigente proibição seja obstativa ao reconhecimento hodierno da morte digna no Brasil.

Palavras-chave: Dignidade da Pessoa Humana; Autonomia Privada; Direitos da Personalidade; Diretivas Antecipadas de Vontade; Morte Digna.

\section{INTRODUÇÃO}

O presente trabalho tem por mote o tratamento do testamento vital como uma espécie autônoma de negócio jurídico unilateral, com a aptidão para promover a morte digna, indagando-se, por outro lado, se este ideal foi realmente salvaguardado na ordem jurídica brasileira, tendo-se em vista a proibição da eutanásia no Código Penal. Apesar da vedação legal, submete-se a teste a subsistência de norma desse jaez numa ordem jurídica que positiva em seu ápice os valores da dignidade humana e da autonomia privada.

Assim, em face das diretrizes que nortearam essa pesquisa, procurou-se, numa primeira fase, mediante método dialético e dedutivo, abordar as premissas teórico-filosóficas do raciocínio a ser expendido, o que consiste

\footnotetext{
${ }^{1}$ Livre-docente e Doutor em Direito Civil pela PUC-SP, da Facoltà di Giurisprudenza della Seconda Università degli Studi di Napoli, Itália, e da Escola Paulista da Magistratura. Titular da Cadeira n. ${ }^{\circ} 73$ da Academia Paulista de Direito. E-mail: rogeriodonnini@uol.com.br

${ }^{2}$ Mestrando em Direito Civil pela PUC-SP.E-mail: raphael_abs@hotmail.com
} 
em passar por ideias como as da dignidade da pessoa humana, da autonomia privada, dos direitos da personalidade e dos esclarecimentos terminológicos relativos a eutanásia, distanásia e ortotanásia.

As questões acima indicadas configuram passagens imprescindíveis para a discussão concernente à morte digna, expressão de imensa amplitude semântica que pode receber contornos dos mais diversos, a depender de fatores socioculturais que a conformam. O tema é fartamente discutido por autores tanto do Common Law como do Civil Lawe, curiosamente, parece que em significativa medida, a despeito de saírem de pontos de partida muito diversos, convergem nas conclusões sobre o respeito à dignidade do ser humano, principalmente com relação ao julgamento que compete a cada indivíduo acerca do que vem a ser uma vida digna. A pesquisa a partir da literatura jurídica nacional e estrangeira ainda deve ser combinada com a coleta jurisprudencial, selecionando-se algumas decisões que se tenham debruçado sobre o tema, com especial cuidado para recente acórdão da Suprema Corte do Canadá, que em 2015 teve a oportunidade de apreciar o tema, num cenário legislativo similar ao brasileiro.

É verdade que todas essas etapas são incontornáveis para um investigador que se propõe a pesquisar, no âmbito da ciência do direito, uma categoria jurídica capaz de respeitar a liberdade do particular no tocante às escolhas que pretende fazer prospectivamente em certo estágio da vida. Apesar da essencialidade desses assuntos, há que se aclarar desde as primeiras notas deste trabalho que o percurso projetado visa à construção de trilha filosófico-normativa com aptidão para se guiar ao exame das debatidas declarações de vontade, cujo conteúdo abrange o eventual tratamento a ser recebido pelo declarante que, por acontecimento posterior, encontra-se incapacitado ou em estado terminal.

Dessa maneira, em fase mais avançada do trabalho, imerge-se numa leitura dogmática do instituto popularmente chamado de testamento vital, com a finalidade de expô-lo sob a ótica da teoria geral do negócio jurídico - neste caso, por força da natureza do objeto, adjetivado de existencial ou extrapatrimonial -, passando-se por rico arcabouço doutrinário que permite compreendê-lo de maneira precisa, de acordo com a técnica proposta pelos civilistas do tronco romano-germânico.

Ao término, todo o percurso traçado possibilita a discussão concernente à extensão da morte digna, que não deixa de ser objeto do testamento vital, porquanto a delimitação do objeto dessa categoria negocial permite debater a efetiva proteção desse ideal na ordem jurídica brasileira.

\section{A DIGNIDADE DA PESSOA HUMANA}

Ao centrarem-se a liberdade e a morte digna como cerne da presente investigação científica, torna-se indispensável iniciar os trabalhos pela abordagem da dignidade da pessoa humana, princípio que fundamenta a ordem constitucional brasileira (art. 1º, III, da Constituição da República Federativa do Brasil - CRFB). Embora 
surrada na retórica jurídica pátria, a aludida norma basilar é resultado de um amadurecimento antropológico ocidental, refletindo, portanto, imensa carga axiológica, a qual requer comentários específicos para que não se repita o erro bastante usual de mencioná-la sem saber ao certo qual seu significado nuclear ${ }^{3}$, ainda que seja irrecusável a impossibilidade de traçar uma definição terminativa, já que, na prática, verifica-se sua aplicação conforme a tópica (FERRAZ JUNIOR, 2008, p. 303-4; VIEHWEG, 1964, p. 38).

\section{Histórico Filosófico}

Decerto, consoante o escancarado desiderato deste artigo, não é possível aqui percorrer-se longa trajetória histórica no tocante às primeiras fontes em que se constatam as menções à dignidade humana. Por outro lado, seria temerário direcionar-se imediatamente ao aspecto normativo constitucional sem previamente apresentar ao menos os mais importantes marcos históricos na civilização ocidental que contribuíram para moldar esse moderno princípio jurídico de observância internacional.

Dessa forma, acolhe-se preliminarmente a advertência de Ingo Wolfgang Sarlet (2012, p. 34-5), que, ao discorrer a respeito do desenvolvimento histórico da dignidade humana no pensamento ocidental, explica que, embora sejam atitude de pouca cautela afirmações peremptórias a respeito da origem de uma determinada expressão, tem-se a impressão de que o investigado termo encontra amparo originário na antiguidade clássica, especialmente no estoicismo e, tempos depois, no cristianismo.

Observe-se, no entanto, que, ao pesquisar-se sua etimologia, a palavra dignitas nasce com emprego distinto do modernamente utilizado, de forma que, nesse primeiro momento, denotava posição social, status, cargo, títulos ou honraria, ou, ainda, posição socialmente vantajosa de certo sujeito ao deparar-se com uma dada situação (ROCHA, 2016). ${ }^{4}$

Somente com as revoluções liberais do século XVIII nota-se a guinada semântica da expressão, ${ }^{5}$ momento em que a palavra dignidade é apropriada pelo discurso político, atribuindo-lhe então o sentido genérico

\footnotetext{
${ }^{3}$ Em suma, na esteira das lições de Karl Engisch (1996, p. 209), o intento é o de buscar o núcleo conceitual da dignidade humana enquanto conceito propriamente jurídico. A crítica a que se refere o texto, dessarte, se volta às situações em que o interlocutor utiliza o termo "dignidade humana" sem que esteja no halo conceitual, ou, se nele estiver, haja substanciosa dúvida acerca da coerência semântica - esta zona de incerteza pode ser qualificada como cinzenta.

${ }^{4}$ A essa menção bibliográfica deve ser feita uma ressalva, na esteira das lições de Ingo Sarlet (2012, p. 35), que aponta como exceção à semântica precursora o sentido conferido pelo pensamento estoico, sempre fincado na noção de que a dignidade era atributo inerente a todos os seres humanos, característica que os distinguia dos demais seres vivos, sem, todavia, hierarquizar ou estabelecer graus de dignidade entre os homens, o que confluía para os ideais de igualdade, liberdade e responsabilidade pelos atos praticados por cada sujeito.

${ }_{5}^{5}$ Observe-se, no entanto, que, na Declaração dos Direitos do Homem e do Cidadão, de 26 de agosto de 1789, ainda previu-se a dignidade com o sentido originário, desvinculado da moderna concepção prevista nas Constituições do século XX, conforme a seguinte disposição que se extrai na literalidade: "VI. A lei é a expressão da vontade geral. Todos os cidadãos têm direito de contribuir pessoalmente, ou pelos seus representantes, à sua formação. Deve ser a mesma para todos, seja para fins de proteção ou punição. Todos os cidadãos iguais aos seus olhos são igualmente admissíveis a todas as dignidades, lugares e empregos públicos, de
} 
até os dias de hoje constatável, qual seja a percepção de uma característica inerente ao homem, pensada como mecanismo de proteção da integridade e inviolabilidade não só da perspectiva física, mas também da existencial de maneira ampla (ROCHA, 2016).

De toda forma, encerrando-se a digressão etimológica e retomando-se o escorço histórico-filosófico, Antigo e Novo Testamentos fazem alusão à criação do homem à luz da imagem e da semelhança com Deus, ponto em que o cristianismo extraiu a ideia conforme a qual todo homem, ainda que não fosse adepto dos dogmas cristãos, tem um valor intrínseco que impede sua instrumentalização. ${ }^{6}$

No Direito Romano, por sua vez, Marco Túlio Cícero - apontado como o primeiro escritor a utilizar a expressão "dignidade do homem" (BARROSO, 2012, p. 132) - consegue elaborar um sentido dúplice à dignidade, abarcando tanto a noção de posição social como a moral, vinculada à meritocracia e à integridade (CÍCERO, 1913, p. 107). A partir de então, prepondera esse sentido ambivalente da dignidade, que se estende por séculos durante a Idade Média.

Avançando-se para um dos principais pensadores medievais, São Tomás de Aquino em pleno século XIII também se refere à dignitas humana como característica exclusiva da alma de cada homem, cuja natureza é salientada pelo exercício da razão, isto é, da autodeterminação, permitindo-lhe, então, observar a lei natural (AGUAS, 2009, p. 55), 7 ponto em que se abre a conexão com a obra do célebre renascentista Giovanni Pico della Mirandola (2006, p. 55), a De hominis dignitate oratio, na qual também havia - ainda que não exclusiva - forte influência do pensamento cristão.

Giovanni Pico della Mirandola entende que a racionalidade é a característica distintiva do ser humano, a qual lhe permite ditar seu próprio destino. Como havia uma inspiração antropocêntrica muito mais acentuada se confrontada com o pensamento tomista, Giovanni Pico della Mirandola salienta o livre-arbítrio como elemento que alça a superioridade do homem em relação às demais espécies, exaltando a aptidão humana para atingir os objetivos traçados (PICO DELLA MIRANDOLA, 2006, p. 57).

Mais adiante, nas colonizações que foram resultado das grandes navegações, verifica-se nos escritos pioneiros do Direito Internacional Público, então chamado de ius gentium, a posição humanista de Francisco de Vitoria, que, partindo dos ideais estoicos e cristãos, refuta a escravização e a exploração dos indígenas americanos,

acordo com a sua capacidade, e sem outra distinção que não seja a das suas virtudes e dos seus talentos”. Disponível em: <http://www.conseil-constitutionnel.fr/conseil-constitutionnel/root/bank_mm/portugais/constitution_portugais.pdf>. Acesso em: 17 abr. 2016.

${ }^{6}$ A fim de demonstrar o afirmado no texto, traz-se a seguinte passagem bíblica: Gn 1, 26-28 (2016): "26. E disse Deus: Façamos o homem à nossa imagem, conforme a nossa semelhança; domine ele sobre os peixes do mar, sobre as aves do céu, sobre os animais domésticos, e sobre toda a terra, e sobre todo réptil que se arrasta sobre a terra. 27. Criou, pois, Deus o homem à sua imagem; à imagem de Deus o criou; homem e mulher os criou. 28. Então Deus os abençoou e lhes disse: Frutificai e multiplicai-vos; enchei a terra e sujeitai-a; dominai sobre os peixes do mar, sobre as aves do céu e sobre todos os animais que se arrastam sobre a terra”.

${ }^{7}$ Os comentários de Aguas, ademais, pautam-se na Parte I, Questão 29, Artigo 3o da Summa Theologica (2016). 
haja vista a igualdade e a liberdade também gozadas por estes últimos em função da idêntica natureza humana, além do direito natural incidente a todos os homens, conquanto não fossem católicos ou protestantes (OLIVEIRA, 1973, p. 371-2).

Nesse constante processo evolutivo, a partir das revoluções liberais dos séculos XVII e XVIII, a noção de dignidade da pessoa humana se laiciza e se racionaliza, mas nem por isso deixa de perder a essência respaldada na ideia de igualdade de todos os homens no tocante à dignidade. Apenas com Samuel Pufendorf (1734, t. I, p. 130), entretanto, há uma explanação da dignidade totalmente despida de valoração religiosa, apontando-se a liberdade moral do homem como elemento que lhe é peculiar, neste sentido significando a faculdade de fazer escolhas conforme sua intelecção. ${ }^{8}$

Em que pesem as relevantes contribuições teóricas acima lembradas, a obra que realmente marca época no pensamento filosófico ocidental é Fundamentação da metafisica dos costumes, de Immanuel Kant, publicada em 1785 na Prússia, momento em que de fato se verifica uma concepção definitivamente desvinculada do cristianismo - isso, porém, não afasta a importância de autores como São Tomás de Aquino e Boécio para a formação do pensamento kantiano -, na medida em que o autor procura assentar a dignidade na autonomia ética do ser humano (SARLET, 2012, p. 40).

Nesse diapasão, concebendo o homem como um fim em si mesmo, que não se sujeita ao arbítrio de outrem, Kant (1967, p. 89) compreende a autonomia da vontade como a faculdade de determinar-se e de agir consoante a lei, a qual configura atributo próprio dos seres racionais, além de servir de fundamento para a dignidade. Logo, nota-se aqui a profunda interação entre autonomia e dignidade, a repercutir no ponto de vista ocidental até os presentes dias. ${ }^{9}$ Além disso, ainda nessa linha intelectiva, não se esqueça da ideia segundo a qual aquilo que tem dignidade não pode ser objeto de precificação, reforçando-se mais uma vez a noção de que todos os homens são merecedores de tratamento digno - conforme a célebre expressão kantiana, são fins em si $\operatorname{mesmos}^{10}$-, de forma a obstar qualquer tentativa de tratá-los como coisas ou meios. Ao contrário, existe um

\footnotetext{
${ }^{8}$ Deveras, há uma intensa disputa entre os estudiosos da obra de Pufendorf: se ele teria ou não fundado a igualdade natural com base na dignidade humana - linha interpretativa de Hans Welzel, pai da teoria finalista da ação no Direito penal, segundo a qual a dignidade humana foi valor basilar para que Pufendorf elaborasse sua teoria do direito natural, em antecipação à obra de Kant. Kari Saastamoinen (2010, p. 40-1), contudo, rebate essa corrente, ao asseverar que a dignidade para Pufendorf significava apenas a superioridade do homem com relação aos outros seres vivos, e não a ideia kantiana de valor humano absoluto e incomparável

${ }^{9}$ Note-se que, no texto, a restrição ao ponto de vista ocidental não é por acaso, pois, trilhando-se a advertência de Ingo Sarlet (2012, p. 68), o multiculturalismo se apresenta como noção ínsita à dignidade, que jamais poderá ser a mesma para qualquer pessoa em qualquer ponto do globo terrestre, constatando-se, destarte, alguma tensão ao se analisar se determinada conduta afronta ou não a dignidade da pessoa humana. Ademais, além do aspecto cultural, as oscilações conceituais também se devem ao local e à época em que contextualizada a discussão, de acordo com o pensamento convergente de Ronald Dworkin (2009, p. 334). Nesse sentido, perceber-se-á que os comentários lançados nesta nota se repetem no transcorrer da presente seção.

${ }^{10}$ Há trecho da citada obra de Kant (op. cit., p. 90-2) em que resta claro seu pensamento: "o homem, e em geral todo ser racional, existe como fim em si mesmo, não só como meio para qualquer uso desta ou daquela vontade; em todas as suas ações, deve, não só nas dirigidas a si mesmo, como também nas dirigidas aos demais seres racionais, ser considerado sempre ao mesmo tempo como
} 
direito de cada indivíduo de ser respeitado em sua dignidade, assim como, na outra ponta, há um dever geral de respeito ao homem, imposto sobre todos os membros da sociedade.

Essa, enfim, a concepção que prevalece nacional e internacionalmente até os dias de hoje, apesar de posteriores amadurecimentos que partiram da visão kantiana e de divergências ou críticas contra o robusto antropocentrismo verificável nessa formulação, podendo-se pô-la à prova mediante a análise dos diversos diplomas normativos editados em ordenamentos jurídicos internos e também no plano internacional, máxime no transcurso do século XX, ao término das duas grandes guerras (SARLET, op. cit., p. 42-46). ${ }^{11}$

Antes, todavia, de proceder-se à breve menção desses marcos histórico-normativos, convém enaltecer, independentemente das profundas divergências doutrinárias que se pôde constatar nos últimos séculos, o importante resquício do pensamento jusnaturalista do século XVIII, contemporaneamente ainda perceptível nas reflexões a respeito, no sentido de reconhecer ao homem, pelo só fato de sua condição humana, sem tomar-se em consideração qualquer outro pormenor, a titularidade de direitos que hão de ser reconhecidos e respeitados pelos concidadãos e pelo Estado - logo, prerrogativas que precedem a própria existência do ente estatal. ${ }^{12}$

\section{A positivação da dignidade da pessoa humana: os aspectos axiológicos e normativos}

Conforme se adiantou na seção precedente, as atrocidades cometidas pelas duas guerras mundiais principalmente com o nazifascismo, por intermédio do Holocausto, perpetrado nos campos de concentração alemães ao longo da Segunda Guerra Mundial ${ }^{13}$-, exigiu da humanidade, após o término do referido período,

fim. (...) O imperativo prático será, pois, como segue: age de tal modo que possas usar a humanidade, tanto em tua pessoa como na pessoa de qualquer outro, sempre como um fim ao mesmo tempo e nunca somente como um meio" (grifo do autor).

${ }^{11}$ A exemplificar a divergência, Sarlet (2012, p. 46) se refere à refutação por Hegel de que a dignidade seria ontológica, pois, em seu modo de ver, o homem só se tornaria digno após conquistar a condição de cidadão. Portanto, trata-se de uma consequência da admissão como membro participante da comunidade política. Avançando-se no tempo, o debate moderno se cinge ao reconhecimento de direitos ou de dignidade a animais e seres vivos. Em suma, o que se pretende enfatizar é a impossibilidade de a dignidade servir de fundamento para que o homem se sobreponha às demais criaturas. Muito pelo contrário, a dignidade da pessoa humana cria obrigações para com os outros animais, somadas aos deveres mínimos de proteção. Similar crítica se nota nos escritos de Antonio Junqueira de Azevedo (2002, p. 112), que procura repelir a ideia segundo a qual a dignidade se assenta na razão e na vontade (concepção insular), uma vez que os chimpanzés também as têm, consoante estudos combinados da biologia, da etologia e da primatologia. Por tal motivo, prega um novo conceito de dignidade humana, que enfatize sobretudo a capacidade dialógica do homem (aspecto intersubjetivo) e a relação de alteridade, reconhecendo-se no próximo uma pessoa merecedora de idêntico respeito.

${ }^{12}$ A origem judaico-cristã e europeia da noção atinente à dignidade cria difíceis empecilhos de ordem cultural e religiosa, que precisam ser superados para se ter sucesso na universalização de uma concepção secularizada da dignidade da pessoa humana (SARLET, op. cit., p. 48).

${ }^{13}$ Neste tema, interessante abordagem voltada para os operadores do Direito Penal é realizada por Francisco Muñoz Conde (2005), que aborda a participação do festejado penalista germânico em projetos de leis nazistas que aviltavam a dignidade de judeus, ciganos, miseráveis, entre outros grupos alvo das barbáries cometidas no período de governança de Adolf Hitler. Outra obra de relevo para esquadrinhar-se a presente passagem do escorço histórico-normativo é a de Fábio Konder Comparato (2006, p. 210). Ademais, Celso Lafer (1988, p. 108-9) adverte, com base nas lições de Arendt, que os regimes de Hitler e de Stalin fogem à relação entre ética e política nos termos do pensamento clássico, pois causaram o total colapso da moralidade no formato 
uma rápida reação aos abusos cometidos. Assim, detecta-se já no preâmbulo da Carta da Organização das Nações Unidas $(\mathrm{ONU})^{14}$ a explícita referência à dignidade humana, de forma a consagrar historicamente o início de sua previsão normativa, três anos depois se repetindo similar disposição na Declaração Universal dos Direitos Humanos $^{15}(1948)$.

É evidente que a cristalização da dignidade humana no âmbito internacional, independentemente de aderir-se à teoria monista ou dualista no concernente à interação do direito internacional com o direito interno, reflete sobre os poderes constituintes dos diversos Estados que passaram por uma mudança constitucional no limiar ou durante a segunda metade do século XX.

Por isso, a partir da Lei Fundamental de Bonn, promulgada em 1949, inaugura-se o rol de Constituições que passaram a prever a dignidade humana não só como valor, mas também como norma fundante de toda a ordem jurídica, prevendo-se, destarte, no artigo 1.1 que "A dignidade da pessoa humana é intangível. Respeitá-la e protegê-la é obrigação de todo o poder público". ${ }^{16}$

Seguindo-se a inspiração germânica, as Constituições portuguesa ${ }^{17}$ e espanhol ${ }^{18}$, nessa respectiva ordem histórica, passaram igualmente a prever em 1976 e em 1978 a dignidade da pessoa humana em dispositivos iniciais, configuradores dos pilares axiológicos e normativos eleitos por esses constituintes.

Finalmente, para que importa a este trabalho, embora se verificasse na Constituição de 1967 uma sucinta menção, na CRFB de 1988 previu-se verdadeiramente como princípio fundamental da República a dignidade da

tradicional, com a representação, por intermédio de um regime totalitário, de uma imensa intromissão da criminalidade no meio político. O trecho a seguir é bastante elucidativo: "Num regime totalitário as pessoas, como observa Hannah Arendt, não agem anarquicamente e não cometem crimes ao acaso, por força dos acidentes da fortuna: 'they too act according to a law, but this law has become the opposite of those laws which are behind all legal systems'. É a reversão do Decálogo: Hitler disse: matarás; e Stalin: darás falso testemunho contra o teu vizinho" (grifo do autor).

${ }^{14}$ Consta do Preâmbulo: "Nós, os povos das nações unidas, resolvidos a preservar as gerações vindouras do flagelo da guerra, que por duas vezes, no espaço da nossa vida, trouxe sofrimentos indizíveis à humanidade, e a reafirmar a fé nos direitos fundamentais do homem, na dignidade e no valor do ser humano, na igualdade de direito dos homens e das mulheres, assim como das noções grande e pequenas, e a estabelecer condições sob as quais a justiça e o respeito às obrigações decorrentes de tratados e de outras fontes do direito internacional possam ser mantidos, e a promover o progresso social e melhores condições de vida dentro de uma liberdade ampla" (grifo nosso).

${ }^{15}$ In verbis: "Considerando que o reconhecimento da dignidade inerente a todos os membros da família humana e seus direitos iguais e inalienáveis é o fundamento da liberdade, da justiça e da paz no mundo, (...) Artigo 1º. Todos os homens nascem livres e iguais em dignidade e direitos. São dotados de razão e consciência e devem agir em relação uns aos outros com espírito de fraternidade. (...) Artigo 22. Todo homem, como membro da sociedade, tem direito à segurança social e à realização, pelo esforço nacional, pela cooperação internacional e de acordo com a organização e recursos de cada Estado, dos direitos econômicos, sociais e culturais indispensáveis à sua dignidade e ao livre desenvolvimento de sua personalidade. Artigo 23 (...) III - Todo homem que trabalha tem direito a uma remuneração justa e satisfatória, que lhe assegure, assim como a sua família, uma existência compatível com a dignidade humana, e a que se acrescentarão, se necessário, outros meios de proteção social”.

${ }^{16}$ Lei Fundamental de Bonn, conforme tradução de Assis Mendonça e revisão jurídica de Urbano Carvelli (2011).

17 "Artigo 1. República Portuguesa. Portugal é uma República soberana, baseada na dignidade da pessoa humana e na vontade popular e empenhada na construção de uma sociedade livre, justa e solidária”.

18 "Artículo 10. 1. La dignidad de la persona, los derechos inviolables que le son inherentes, el libre desarrollo de la personalidad, el respeto a la ley y a los derechos de los demás son fundamento del orden político y de la paz social”. 
pessoa humana (art. $\left.1^{\circ}, \mathrm{III}\right)^{19}$, inclusive tomada por muitos como valor fonte de todos os direitos fundamentais elencados no art. $5^{\circ}$ e noutras normas constitucionais esparsas.

Esse percurso, portanto, ilustra a disseminação da dignidade humana para além das obras filosóficas, adquirindo a conotação jurídico-normativa a partir dos diversos textos constitucionais anteriormente citados malgrado ser importante reconhecer, conforme advertência de Sarlet (2012, p. 79), que está longe de estar universalizada a todas as Constituições atuais.

Por conseguinte, a dignidade da pessoa humana deixa de ser apenas uma preferência axiológica notada em determinados contextos socioculturais, introduzindo-a como categoria jurídica de natureza principiológicaconstitucional - sem desprezar, é claro, o jaez de regra -, de forma a exigir do hermeneuta o tratamento como valor e como norma jurídica, consequentemente passando pelas técnicas constitucionais atreladas à relatividade dos direitos fundamentais e ao sopesamento de princípios, razão por que se dedica tópico próprio ao tema mais adiante. Assim, explicada a consequência da estrutura normativa, a carga axiológica demonstra que o constituinte optou por enfrentar o Estado Democrático de Direito - estruturado e fundamentado pela dignidade - como existente em função da pessoa humana, uma vez que esta deve ser a principal finalidade da atividade estatal (SARLET, op. cit., p. 80), abraçando-se, portanto, os ideais paulatinamente discorridos nas obras filosóficas outrora aludidas, mas com especial balizamento no pensamento de Immanuel Kant, que repele a coisificação do homem.

Em suma, é o Estado que deve servir de vetor para o fomento da cláusula geral da dignidade da pessoa humana ${ }^{20}$ - opostamente às manchas verificadas nas grandes guerras -, vista como promotora da existência do homem em perspectivas concretas, e não de maneira abstrata e distante da realidade. ${ }^{21}$

\section{Tentativas conceituais}

Como se vem afirmando em diversas passagens deste trabalho, a procura por uma definição da dignidade humana é algo que, sem exageros, pode ser considerada impossível.

No entanto, são louváveis as tentativas conceituais de muitos autores que se dedicaram ao tema, ensejando, por esta razão, o exame de algumas das principais posições ventiladas na doutrina brasileira, pois, ainda

\footnotetext{
${ }^{19}$ Observe-se que a Constituição de 1967 já previa a dignidade humana, no art. 157, II ("valorização do trabalho como condição da dignidade humana"), porém de maneira bem distinta daquela posteriormente concebida em 1988, já que, naquela ocasião, vinculada aos princípios da ordem econômica e social, demonstrando o indigitado dispositivo que ela era um pressuposto para o princípio da valorização do trabalho.

${ }^{20}$ Gustavo Tepedino (2002, p. XXV) se refere ao art. 1º, III, da CRFB como cláusula geral de tutela e promoção da pessoa humana. Similarmente, Cortiano Junior (1998, p. 46-7) indica que essa mesma ideia é corroborada pelo direito geral de personalidade, que induz a abertura dos direitos da personalidade para além de um rol meramente fechado.

${ }^{21}$ Nesse sentido, Fachin e Pianovski (2016, p. 3) optam nitidamente por posição que aproxima a dignidade a uma concepção jusnatural, que independe do reconhecimento estatal.
} 
que a expressão seja de difíil conceituação, elementos nucleares desta noção podem ser alcançados, propiciandose, então, útil ferramental teorético que auxiliará esta investigação científica a lidar com as questões atinentes à morte digna sob o regime constitucional pátrio.

Dessa maneira, preliminarmente importa fazer uma observação filosófica respeitante às expressões "conceito" e "definição".

Seguindo-se o magistério da corrente lógico-constructivista, explana Paulo de Barros Carvalho (2011, p. 120) que esses termos são inconfundíveis, uma vez que o conceito é a noção abstrata presente numa palavra para albergar propriedades e características de determinada classe; ao revés, a definição consiste em operação lógica de demarcação dos limites semânticos de determinada ideia, noção ou conceito. Logo, quanto mais elaborada a definição, maiores as chances de reduzir um espectro de vagueza e ambiguidade semântica, na medida em que se trazem mais detalhes para descrever o objeto, por intermédio da combinação de predicados e juízos sobre os atributos dessa classe (BRITTO, 2014, v. I, p. 227 e 238).

Esses esclarecimentos preambulares, portanto, só vêm a confirmar a salientada dificuldade em definir a dignidade humana, embora isso não impeça a análise buscada por relevantes trabalhos nacionais.

Dessa forma, iniciando-se pela proposta apresentada por Ingo Sarlet (2012, p. 73), o próprio autor confessa que o conceito por ele formulado sofreu mutações ao longo das várias edições, tendo, assim, o intuito de reforçar a base multidimensional, aberta e inclusiva da dignidade - o que parece mais uma vez reforçar a aplicação tópica. Deveras, se há uma impossibilidade em definir a dignidade da pessoa humana, o mencionado jurista se vale da abordagem que propugna o aspecto multifacetário da noção de dignidade, nela se abrangendo as dimensões: ontológica, histórico-cultural, negativa, prestacional, objetiva, subjetiva e, por imperativos mais contemporâneos, ecológica.

Tentando-se, por ora, destrinchar essas características essenciais identificadas pelo autor, o aspecto ontológico diz respeito à sua vinculação com o homem, um atributo inato, independentemente de qualquer outra condição ou reconhecimento estatal. O caráter histórico-cultural, a seu turno, fundamenta-se na concepção de que os fatos marcantes que moldaram uma sociedade somados aos valores morais por ela adotados interferem diretamente sobre o significado da dignidade, acentuando-se, noutras palavras, o traço de variabilidade multicultural. Ademais, as dimensões negativa e prestacional se referem, de modo muito simplificado, respectivamente, aos direitos fundamentais da primeira geração, consistentes nos direitos políticos e na liberdade, como formação de esfera protetiva do indivíduo em face do poderio estatal - portanto, de viés tipicamente liberal - e aos da segunda geração, consubstanciados nos direitos sociais de emblemático reconhecimento a partir das Constituições Mexicana (1917) e de Weimar (1919), os quais exigem do poder público uma ação positiva 
(prestação) no sentido de oferecer determinados serviços que garantam condições mínimas de existência e convivência (BONAVIDES, 2010, p. 564).

Por fim, as facetas objetiva e subjetiva se atêm, nesta mesma ordem, ao status de princípio e norma-fonte dos direitos fundamentais. A última dimensão, a ecológica, não tem por escopo reconhecer uma dignidade não humana, mas aponta para deveres que se impõem à humanidade para a preservação do meio ambiente ecologicamente equilibrado, podendo-se aqui exemplificá-la com a explícita positivação em patamar constitucional (art. 225 da CRFB ${ }^{22}$ ) e em legislação própria à salvaguarda dos direitos difusos (art. $1^{\circ}$ da Lei n. ${ }^{\circ}$ 7.347/1985, combinado com art. 81, parágrafo único, I, do Código de Defesa do Consumidor). ${ }^{23}$

Entretanto, ainda no mesmo excerto, importante salientar a ressalva feita pelo próprio autor (SARLET, op. cit., p. 73) no tocante à indispensável necessidade de testar essa conceituação com base na relação concreta entre dignidade da pessoa humana e direitos fundamentais, pois o conteúdo de ambas as categorias só será materializado e tornado operacional diante das circunstâncias fáticas e jurídicas que o caso concreto ofereça ao exegeta.

Em breve digressão, alterando-se um pouco o ponto de vista daquele que concebe a noção abstrata de dignidade, se se tomar em consideração as ideias lançadas por Ronald Dworkin, perceber-se-á nitidamente como o aspecto histórico-cultural influencia de forma incisiva a concepção de cada autor.

Essa afirmativa se justifica no presente caso, uma vez que o norte-americano (2009, p. 314) trata a dignidade como a capacidade de amor-próprio do ser humano, posteriormente mais bem desenvolvida para significar o direito que impõe aos demais o dever de reconhecer os interesses críticos de seu titular, enfatizando a importância intrínseca, objetiva e pessoal da vida humana (Ibid., p. 337); finalmente, nas notas derradeiras, parece concluir no sentido de que a dignidade só pode ser efetivada se houver o real exercício de autonomia - ou, em termos mais amplos, da liberdade individual, aqui também albergando a liberdade de consciência num Estado Democrático de Direito -, afastando, por outras palavras, o intervencionismo público ou o juízo de terceiros na tomada de decisões sobre o destino da vida de cada pessoa (Ibid., p. 342-3).

Indo-se adiante, como contraponto ao pensamento de Dworkin, externado em meados da década de 90, pode-se por último rememorar a linha de raciocínio apresentada por Antonio Junqueira de Azevedo (2002, p. 109), o qual, no começo dos anos 2000, propõe uma releitura do princípio constitucional da dignidade da pessoa humana, com o objetivo de salientar o anacronismo da posição que explanava o referido preceito normativo nos

\footnotetext{
${ }^{22}$ Isso fica claro na leitura do caput do citado dispositivo, na medida em que o constituinte estabeleceu o dever de proteger e preservar o meio ambiente ecologicamente equilibrado tanto ao poder público como à coletividade: "Art. 225. Todos têm direito ao meio ambiente ecologicamente equilibrado, bem de uso comum do povo e essencial à sadia qualidade de vida, impondo-se ao Poder Público e à coletividade o dever de defendê-lo e preservá-lo para as presentes e futuras gerações".

${ }^{23}$ Nesse contexto, Miguel Reale, em escrito de janeiro de 2004, reconhece o direito ao meio ambiente ecologicamente equilibrado como novo direito da personalidade.
} 
termos da concepção originária - chamada pelo autor de insular -, de acordo com a qual a dignidade humana se resume à autonomia individual, ou à autodeterminação.

A fim de refutar essa visão tradicional, Junqueira de Azevedo (Ibid., p. 115) perpassa por algumas premissas que vão desde os estudos mais recente advindos da biologia (evolução das espécies), passando pela etologia (especialmente pela primatologia) até chegar às novas descobertas acerca do cérebro humano, tudo com o intento de asseverar que o homem não é o único ser vivo dotado de autoconsciência, de maneira a tornar insuficiente a noção de que a dignidade se resume à autonomia individual.

Ao término, conclui que a segunda concepção, defendida pelo indigitado jurista brasileiro, encara a dignidade "como qualidade do ser vivo, capaz de dialogar e chamado à transcendência", de forma a reconhecer que o ser humano "não é o único ser inteligente e capaz de querer, ou o único dotado de autoconsciência. Há, entre os seres vivos, um crescendo de complexidade e o homem é o último elo da cadeia”. Assim, na esteira de Junqueira de Azevedo, arrimando-se em sua concepção acerca da dignidade da pessoa humana, importa reconhecer, conforme terminologia kantiana, a intangibilidade da vida como imperativo jurídico categórico, tratando-a como valor absoluto. Todavia, as consequências da dignidade, em atendimento à especificidade do homem, resumidas no respeito às integridades física e psíquica, nas condições mínimas de vida e nos pressupostos mínimos de liberdade e igualdade são vistas como imperativos jurídicos relativos, o que as coloca em patamar hierarquicamente inferior diante daquele preceito absoluto (Ibid., p. 122-3). ${ }^{24}$

Essa meditação sobre posições antagônicas demonstra a riqueza histórico-cultural ${ }^{25}$ subjacente à noção de dignidade da pessoa humana, repercutindo decisivamente na discussão relativa à liberdade e à morte digna, pois, naturalmente, aqueles que aderirem à intangibilidade da vida humana - a autoproclamada concepção

\footnotetext{
${ }^{24}$ Esse é basicamente o cerne do artigo publicado pelo jurista, que, no último parágrafo, retoma-o, em parágrafo conclusivo, com a reunião das principais etapas discorridas no texto, merecendo por isso a transcrição a seguir: "Sintetizando tudo que procuramos transmitir com este artigo, concluímos: a. diante da 'confusão geral' criada por gregos e troianos na utilização do princípio jurídico da dignidade da pessoa humana, impõe-se ao jurista brasileiro, evitando uma axiologia meramente formal, dar indicações do conteúdo material da expressão; b. há graves falhas científicas na concepção filosófica da pessoa humana como ser dotado de razão e vontade, ou auto-consciente (concepção insular). Segue-se daí que é insuficiente a idéia de dignidade como autonomia, a que essa concepção dá sustentação. A pessoa humana, na verdade, se caracteriza por participar do magnífico fluxo vital da natureza (é seu gênero mais amplo), distinguindo-se de todos os demais seres vivos pela sua capacidade de reconhecimento do próximo, de dialogar, e, principalmente, pela sua capacidade de amar e sua abertura potencial para o absoluto (é sua diferença específica) (concepção da pessoa humana fundada na vida e no amor); c. com esse fundamento antropológico, a dignidade da pessoa humana como princípio jurídico pressupõe o imperativo categórico da intangibilidade da vida humana e dá origem, em sequência hierárquica, aos seguintes preceitos: 1. respeito à integridade física e psíquica das pessoas; 2. consideração pelos pressupostos materiais mínimos para o exercício da vida; $\mathrm{e}$ 3. respeito às condiçōes mínimas de liberdade e convivência social igualitária”.

${ }^{25}$ No âmbito jurídico, Paulo de Barros Carvalho (2011, p. 174) enfatiza que "... ali, onde houver direito, haverá, certamente, o elemento axiológico". Em consonante linha de raciocínio, para salientar a importância da cultura sobre a atividade interpretativa, Miguel Reale (1996, p. 3) assim a conceitua: "sistema de intencionalidades humanas historicamente tornadas objetivas através da história, ou, por outras palavras, a objetivação e objetivização histórica das intencionalidades no processo existencial”. Na verdade, por ser fruto de criação humana, a cultura se torna fundamental para se compreender a formação e o desenvolvimento do homem (HESSEN, 1946, p. 245).
} 
monista da dignidade - rejeitarão de imediato a possibilidade de admitir-se a eutanásia na ordem jurídica brasileira, além de conceber um espaço muito mais restrito de exercício da autonomia individual se confrontado com o ponto de vista que sugere residir na ideia larga de liberdade a centralidade de uma vida digna. ${ }^{26}$

De toda forma, lançado o delineamento geral, com as evidentes dissidências acerca do que integra o conceito de dignidade da pessoa humana, convém, antes de tratar-se do princípio da autonomia privada, antecipar os comentários referentes ao sopesamento (ou ponderação) dos princípios, por configurar questão fundamental para o deslinde da linha de pensamento instaurada neste trabalho.

\section{A natureza principiológica e o sopesamento de princípios}

Ao abrir-se uma seção própria para discussão sobre o sopesamento de princípios, não se pretende neste breve tópico retomar toda a discussão em torno dos princípios e das regras, tampouco as divergências verificáveis entre os estudiosos quanto às formulações teóricas em torno das espécies normativas.

Em suma, o que se visa ao talhar este trecho é apenas ressaltar algumas características de operabilidade dos princípios jurídicos, as quais serão imprescindíveis para tentar-se apresentar uma proposta de solução à celeuma relativa à admissibilidade e à delimitação do objeto das diretivas antecipadas de vontade.

Se os princípios têm base axiológica, gozando, outrossim, de estrutura normativa, precisam ser assim encarados quando da aplicação e da colisão com outras normas de similar natureza.

Nesse sentido, princípios e regras são espécies do gênero norma, a qual, por sua vez, pode ser definida, sob um viés positivista, como um preceito que engloba um juízo hipotético-condicional, cuja hipótese descreve uma situação fática que, ao materializar-se na realidade, sofre a incidência normativa e, por um vetor deôntico emanando um dever, uma proibição ou uma permissão, produz os efeitos previstos no consequente normativo (CARVALHO, 2014, p. 288).

Essa dicotomia entre as espécies normativas é crucial para a teoria dos direitos fundamentais, mormente porque as normas que os positivam têm a natureza principiológica. Assim, deve-se entender por princípio uma norma jurídica que contém um mandamento de otimização, ordenando que algo seja realizado na maior medida possível diante das circunstâncias de fato e de direito verificáveis no caso concreto (ALEXY, 2008, p. 90). Essa

\footnotetext{
${ }^{26}$ Isso fica claro pelo panorama exposto nesta seção, ao colocar-se lado a lado os pressupostos de Ronald Dworkin e de Junqueira de Azevedo, redundando em posições consideravelmente distintas, porém não menos brilhantes, haja vista a extraordinária atividade argumentativa desenvolvida por ambos os autores. Tem-se a impressão, ademais, de que a conceituação buscada por Ingo Wolfgang Sarlet se situa numa zona intermediária entre as duas supracitadas, já que busca a conciliação das principais ideias ventiladas por cada uma, demonstrando, na medida do possível, a aptidão para se harmonizarem. Isso, todavia, não significa que Ingo Sarlet aceite plenamente as premissas dos raciocínios externados, bastando, apenas a título ilustrativo, lembrar que Junqueira de Azevedo estabelece, a priori, hierarquia entre normas de caráter principiológico quando declara a superioridade absoluta do valor vida, diferentemente do aduzido por aquele autor, cujo raciocínio se escora inclusive na relatividade axiológico-normativa tradicionalmente colhida da obra de Robert Alexy, como se verá no próximo tópico.
} 
oscilação do grau de satisfação é dependente das possibilidades fáticas e jurídicas, sendo estas últimas determinadas de acordo com a colisão de regras e de princípios.

Nesse mesmo critério classificatório, as regras devem ser vistas como normas que ou são totalmente satisfeitas, ou não são satisfeitas, de modo que se deve obedecer exatamente ao prescrito, no âmbito do que é fática e juridicamente possível. Por tal motivo, Ronald Dworkin adverte que as regras se aplicam de forma "tudo ou nada", ao passo que princípios apresentam uma vagueza enunciativa (DWORKIN, 2007, p. 39-40).

Portanto, nesse critério proposto por Alexy, a diferença entre regras e princípios é meramente qualitativa, sem que se possam estabelecer graus entre as aludidas espécies - rompendo-se, portanto, com um dos tradicionais critérios de diferenciação. ${ }^{27}$

Procede-se, então, à análise dos conflitos entre regras e, em seguida, às colisões entre princípios. Primeiramente, se houver um conflito de regras, dever-se-á buscar inicialmente uma cláusula de exceção e, se essa primeira ferramenta não for possível, ter-se-á de declarar inválida uma delas, consequentemente retirando-a do sistema jurídico, pois, como explica o jurista alemão, "não é possível que dois juízos concretos de dever-ser contraditórios entre si sejam válidos" (ALEXY, op. cit., p. 92).

Por outro lado, em se tratando de colisão principiológica, a solução é bastante diferente, já que os princípios têm uma carga, uma dimensão de peso, e por tal razão são sopesados, ponderados no caso concreto, $\mathrm{o}$ que significa dar prevalência, maior eficácia, a um dos conflitantes, porém sem desprezar, refutar, declarar invalidade ou enxertar cláusula de exceção para proteger o preterido. ${ }^{28}$ Ademais, isso variará de acordo com a situação concreta, pois se numa determinada conjuntura um princípio prepondera sobre o outro, este último pode, sem dúvidas, receber maior atenção em face do primeiro se o cenário fático e jurídico for totalmente diverso (ALEXY, op. cit., p. 94).

Fazendo-se brevíssimo alongamento desses comentários, excogita-se a colidência entre um princípio e uma regra, neste caso devendo-se cotejar o primeiro com o princípio-fonte ou estruturante da segunda, prevalecendo aquele caso possa desconstruir a fundamentação deste último.

Ora, se ao lidar com colisão de princípios necessariamente o intérprete deve atribuir pesos a cada um deles, fica escancarada a relatividade dessas normas de forte substrato valorativo, que podem preponderar num determinado cenário e perder sua máxima robustez noutro quadro.

Sem aqui pretender-se universalizar o ponto de vista de Alexy, que sofre, é certo, críticas muito bem construídas na doutrina nacional (AVILA, 2011, p. 78-9), esses despretensiosos esclarecimentos se voltam

\footnotetext{
${ }^{27}$ Trata-se do chamado critério da generalidade, entendendo-se que princípios são normas de elevado grau de generalidade, ao passo que as regras apresentam-na em nível reduzido (ALEXY, op. cit., p. 87).

${ }^{28}$ Nessa passagem, observa-se que Virgílio Afonso da Silva (2002, p. 30) adota concepção segundo a qual há uma regra de proporcionalidade que sob seu manto abrange uma avaliação trifásica consistente nos exames de adequação, necessidade e proporcionalidade em sentido estrito, sendo este ferramental utilizável na hipótese de colisão principiológica.
} 
pragmaticamente ao fornecimento de alguns subsídios teóricos para se poder avançar no raciocínio esquadrinhado neste trabalho, ocupando-se mais propriamente da colisão de normas que prescrevem direitos fundamentais. No presente caso, enfim, pode-se vislumbrar um embate entre a liberdade individual que deriva da dignidade da pessoa humana - resultando, em última análise, na morte digna - e o direito à vida - a vedação à disponibilidade do término da vida pelo sujeito, ou, recuperando-se o imperativo categórico na opinião de Junqueira de Azevedo, a intangibilidade do valor vida -, sem que, ao abraçarem-se os pressupostos rememorados na presente passagem, seja possível determinar prima facie a absoluta vitória de uma norma valorativa sobre outra.

Portanto, nesse cenário movediço, envolto pela relatividade axiológica, deve o hermeneuta progredir na discussão sobre os limites do exercício da liberdade individual no tocante à disponibilidade da própria vida ao defrontar-se com cenário irreversível, por exemplo, um coma, um estado terminal, um estado vegetativo permanente, um estágio avançado do mal de Alzheimer, entre outras situações que exijam intervenções médicas para promoção do prolongamento artificial da vida.

Ainda que Ingo Sarlet (op. cit., p 157-8) aponte a inquestionável predominância na doutrina brasileira do domínio absoluto da dignidade da pessoa humana sobre qualquer outro valor que com ela entre em rota de colisão, há que se entender, primeiramente, que a própria estrutura principiológica da dignidade humana faz com que ela se revista do caráter relativo, identicamente às demais normas previsoras de direitos fundamentais. ${ }^{29}$

Em segundo lugar, dada a difićlima tarefa de conceituá-la, pôde-se demonstrar a ausência de consenso quanto ao seu conteúdo, o que leva, ilustrativamente, a pontos de vista abissalmente incompatíveis, alguns enfatizando como cerne a autonomia privada que dela deriva - verbi gratia, Ronald Dworkin -, enquanto outros preconizando a intangibilidade da vida humana - nesta última vertente alinha-se o ponto de vista de Junqueira de Azevedo -, os quais, para a discussão respeitante à morte digna, chegam a resultados igualmente opostos.

Enfim, essas meditações parecem ser o bastante para encerrar-se o presente tópico, já que amplamente discutida a dificuldade em lidar-se com os axiomas dedutíveis da dignidade humana. Ainda assim, essas são as premissas das quais se parte, na tentativa de traçar um panorama dogmático ao testamento vital e, ao final, oferecer uma proposta harmônica com as proposições asseveradas no curso desta investigação científica.

\footnotetext{
${ }^{29}$ Ainda que a dignidade possa prevalecer em praticamente todos os casos, é incoerente com as premissas teóricas expendidas afirmar, antes mesmo de investigarem-se as circunstâncias fáticas e jurídicas constatáveis na concretude, que a dignidade prevalece sempre em face de qualquer outro valor. Pensa-se, por exemplo, no cerne deste trabalho, consistente em saber se a vida sempre prevalecerá sobre a dignidade do enfermo. A corrente que propugna pela prevalência da primeira, em última análise, estará sempre acolhendo a superioridade hierárquica a priori do valor vida sobre os axiomas dignidade e liberdade individual.
} 


\section{A AUTONOMIA PRIVADA: O VIÉS DA LIBERDADE NO DIREITO PRIVADO}

\section{Relação com o tema em discussão}

De fato, o próximo passo na trilha do pensamento em curso é abordar a autonomia privada, considerando-a o viés da liberdade individual no âmbito do Direito privado.

Ao tratar-se da dignidade da pessoa humana, notou-se que, mesmo entre aqueles que criticam destacar como seu cerne ou sintetizá-la na autodeterminação, há indiscutivelmente como noção integrante do referido conceito a tutela de uma esfera de liberdade individual que decerto não possui contornos rígidos previamente desenhados..$^{30}$

Por conseguinte, na área de aplicação própria ao Direito privado, ramo didaticamente recortado do sistema jurídico com o escopo metodológico de tratar das diretivas antecipadas de vontade, campo natural de concretização deste instituto, o direito fundamental da liberdade individual deve ser visto como o exercício da autonomia privada, a qual, ao menos entre os autores brasileiros, foi e ainda é exaustivamente lembrada ao estudarem-se os contratos. Embora seja irrefutável a importância desse princípio para o Direito contratual, não se pode deixar de aclarar que a ideia de autonomia privada não se atrela exclusivamente às figuras negociais. Muito pelo contrário, assenta-se nos pilares de todo o Direito privado, sendo, portanto, categoria jurídica manejável de maneira ampla pelos ramos privatísticos, inclusive na seara das diretivas antecipadas de vontade - que evidentemente se inserem no âmbito negocial, como se exporá em breve.

Ademais, tem-se a impressão de que o tema "liberdade, morte digna e prolongamento artificial da vida" é fundamentalmente desenvolvido sobre duas colunas teóricas, consubstanciadas na dignidade da pessoa humana e na autonomia privada, princípios estes que se reputam hábeis a providenciar uma solução jurídica à vertente discussão.

\section{O conceito da autonomia privada}

\footnotetext{
${ }^{30}$ Já se escreveu noutra ocasião que (2015, p. 68-69): "Há uma relação direta entre dignidade humana, felicidade, a ideia de não lesar a outrem e bem comum. A dignidade humana é um princípio jusnaturalista, centrado na ideia de liberdade e igualdade, segundo o qual toda pessoa tem, diante de sua simples existência humana, o direito ao respeito à sua dignidade. Contrapõe-se, assim, ao argumento jurídico de mera racionalidade utilitarista”.
} 
Assim como a dignidade, a autonomia privada não deixa de ser um conceito jurídico indeterminado ${ }^{31}$, de irrecusável vagueza semântica, que requer a concretização pelo aplicador, com o intuito de conferir-lhe aos menos um contorno mínimo de sentido entre os interlocutores.

Dessarte, consultando-se importantes obras relativas ao assunto, entende-se que a autonomia privada pode ser reduzida - leia-se, por termos diversos, conceituada - ao direito fundamental de propriedade privada e à capacidade negocial subjetiva. ${ }^{32}$ Observa-se, porém, no tocante ao segundo componente mencionado, que autores como Ana Prata (op. cit., p. 198-9) delineiam a capacidade negocial como figura norteada rigidamente aos negócios patrimoniais, inábil - ao menos no sistema jurídico-constitucional português - a servir como categoria abstrata ao exercício da liberdade individual.

Malgrado aceitar-se a visão da autora de que a capacidade negocial é fundamental para a introdução e consolidação do sistema econômico capitalista em fase de ruptura com o feudalismo, entende-se, na contramão, que no contexto hodierno os horizontes do instituto já foram sobejamente expandidos, a fim de abarcar os negócios extrapatrimoniais (ou existenciais), atos estes que, aliás, como se discorrerá mais adiante, possibilitam inclusive especulações científicas sobre novos requisitos de validade à declaração de vontade posta em análise.

Deixando-se um pouco de lado as discussões acerca do raio semântico da autonomia e da capacidade negocial - e, aproveitando-se rapidamente o ensejo, idêntica celeuma se verifica com o direito subjetivo de propriedade -, para a presente polêmica interessa apenas o segundo elemento, isto é, a capacidade negocial de que goza cada sujeito de direito, podendo exercer a faculdade de praticar os mais diversos atos jurídicos lato sensu, de conteúdo patrimonial ou extrapatrimonial, em nítido poder de criação de um autorregramento à esfera jurídica individual $^{33}$

\footnotetext{
${ }^{31}$ Aqui também já se explicou (2011, p. 160) que a acepção de conceito jurídico indeterminado não refuta a natureza principiológica, ou, ainda, de cláusula geral, pois tudo depende da maneira como se enfocar a função em que utilizada a dignidade da pessoa humana ou a autonomia privada.

${ }^{32}$ Conforme trecho que se extrai de Ana Prata (2016, p. 16-7): "Os mecanismos jurídicos de expressão da liberdade dos sujeitos privados na tutela dos seus interesses - isto é, os instrumentos jurídicos atribuídos aos sujeitos privados para operarem essa tutela são o direito subjectivo (ou a propriedade, como seu paradigma) e a liberdade negocial. Assim, numa perspectiva ampla, poderá entender-se que a noção de autonomia privada se desdobra nestes mesmos dois aspectos essenciais: direito subjetivo e liberdade negocial". A complementar essas ideias, Emílio Betti (1969, t. I, p. 97-8) entende que a autonomia privada tem duas funções distintas: como fonte de normas jurídicas e como pressuposto e causa geradora de relações jurídicas disciplinadas abstrata e genericamente pelo ordenamento.

${ }^{33}$ Explanação que se relaciona com a etimologia do termo "autonomia" (derivado da combinação dos radicais gregos autós e nomos) e consistente na possibilidade de o indivíduo criar normas ou regras a si próprio, ou, mais simplificadamente, no direito de reger-se por leis próprias (HOUAISS, 2009). Na filosofia, em Kant (op. cit., p. 97), apresenta-se o princípio autonomia da vontade como a sujeição do homem à sua própria vontade legisladora universal. Por fim, a clássica concepção de Karl Larenz (1978, p. 55) assim define a autonomia privada, por ele considerada princípio capital do Direito privado: "La posibilidad, ofrecida y asegurada a los particulares por el ordenamiento jurídico, de regular sus relaciones mutuas dentro de determinados limites por medio de negocios jurídicos, en especial mediante contratos, recibe la denominación de autonomía privada". A proposta de Larenz, portanto, coincide com a conceituação stricto sensu reportada por Ana Prata (op. cit., p. 19).
} 
Naturalmente, o testamento vital é decorrência direta da autonomia privada, encontrando respaldo na ordem jurídica pátria sem necessitar de qualquer regulamentação de maior minudência, configurando-se, deste modo, um negócio jurídico unilateral, atípico e extrapatrimonial, como se explicará com mais afinco nas próximas etapas. $^{34}$

Ademais, no que diz respeito aos limites da autonomia privada, adere-se aqui à posição ventilada por Roxana Cardoso Brasileiro Borges (2003, p. 55), segundo a qual esse balizamento é imensamente subjetivo, pautado sobretudo pela dignidade da pessoa humana, que, como já se conseguiu outrora esclarecer, tem substratos histórico, sociológico e cultural muito proeminentes.

\section{A (IN) DISPONIBILIDADE RELATIVA DOS DIREITOS DA PERSONALIDADE}

Neste trecho, não se visa a longas divagações em cada seção, mas se opta pela fragmentação em diversos subtópicos com a finalidade de passar pragmaticamente por ideias que se reputam relevantes para o entendimento do assunto, estruturando-se com transparência as etapas do raciocínio em percurso.

\section{Noções gerais}

Para se tratar da disponibilidade relativa de direitos da personalidade, é preciso preliminarmente abordar algumas ideias básicas relativas à categoria jurídica em comento.

Nesse sentido, embora não se negue a existência de alguns traços embrionários de proteção à pessoa no curso histórico do direito, aponta-se a Escola Pandectista como berço da teoria dos direitos da personalidade. Por conseguinte, Otto von Gierke, que pertencia à Escola Histórica do Direito, é considerado um dos primeiros autores, senão o pioneiro, a escrever sobre os bens da personalidade, que mereciam alguma forma de proteção jurídica. Curiosamente, no entanto, Friedrich Carl von Savigny, muito provavelmente o maior autor da mesma vertente à qual filiado o primeiro, tecia ferrenhas críticas à possibilidade de o homem ser, simultaneamente, sujeito e objeto do direito. ${ }^{35}$

Independentemente dessas antigas discussões, prevaleceu a teoria no âmbito jurídico, de forma que modernamente se reconhecem os direitos da personalidade como poderes jurídicos subjetivos que têm por objeto projeções ou atributos da personalidade humana - consoante lições de Adriano De Cupis (2004, p. 29), os

\footnotetext{
${ }^{34}$ De acordo com a explanação de Emílio Betti (t. I, p. 102): "O negócio é instrumento de autonomia privada, precisamente no sentido de que é posto pela lei à disposição dos particulares, a fim de que possam servir-se dele, não para invadir a esfera alheia, mas para comandar na própria casa, isto é, para dar uma organização básica aos interesses próprios de cada um, nas relações recíprocas”. Curiosamente, perceba-se que o trecho não restringe a aplicabilidade negocial aos interesses patrimoniais, podendo-se aproveitar plenamente as ideias aduzidas de forma a estendê-las à formulação básica das diretivas antecipadas de vontade.

${ }^{35}$ Nesse diapasão, verificam-se os escritos de Rabindranath Sousa (1995, p. 81) e de Francisco Amaral (2008, p. 286-7).
} 
bens de maior valor dignos de salvaguarda pelo Direito -, neste conjunto se incluindo os bens da vida, da integridade tanto física como psicológica, da liberdade, dentre outras extensões numa lógica inexaurível de enumeração.

Há, é verdade, uma longa disputa sobre os fundamentos dos direitos da personalidade, ora se afirmando uma origem jusnaturalista, no sentido de tais poderes serem inatos, inerentes ao homem, sem depender de uma declaração estatal, ora se negando esta primeira assertiva, valendo-se, então, do poder estatal de positivação de normas que tenham por consequência outorgar esses poderes subjetivos individuais. Quando do cotejo dessas duas justificações, percebe-se claramente que aqueles que visualizam os direitos da personalidade como um grupo infindável (numerus apertus) de prerrogativas relativas ao próprio homem - ponto de vista, aliás, com o qual se concorda - conseguem coadunar esta tese com mais facilidade ao fundamento de direito natural, enquanto os que pendem para o positivismo encontram amparo mais harmônico na concepção conforme a qual os direitos da personalidade devem ser previstos num catálogo, isto é, num rol fechado, cuja ampliação só poderá ocorrer mediante ingerência do Estado (TEPEDINO, 2001, p. 39).

A propósito, numa crítica muito pertinente à vertente análise, Roxana Borges explica que a adoção da ideia de tipicidade dos direitos da personalidade enclausura o exercício desses poderes àquelas hipóteses dispostas na CRFB (por exemplo, no art. 5o) e no CC (arts. 11 a 21), raciocínio ultrapassado para a ampla proteção da dignidade humana na sociedade pós-moderna, razão por que, na interpretação da autora, a doutrina nacional tende maciçamente à rejeição da fundamentação positivista (BORGES, op. cit., p. 28-9).

Dessa maneira, predominando entre os autores a concepção de inesgotabilidade, isto consectariamente se reflete nas particularidades e nas diferenças examináveis numa miríade de classificações propostas pelos estudiosos do assunto. Por tal razão, aliado ao recorte metodológico sucinto deste trecho, menciona-se apenas aquela proposta por Limongi França (1980, v. 1, p. 411-2), vastamente disseminada no país, que dividia os direitos da personalidade em projeções físicas, intelectuais e morais, sem, todavia, enrijecê-las, já que um determinado direito podia apresentar mais de uma faceta. Minudenciando-se essas três subdivisões, dentre as principais prerrogativas, a integridade física abarcaria o direito à vida, o direito sobre o próprio corpo, sobre o corpo alheio e sobre partes do corpo (nas três situações, tanto vivo como morto) e o direito aos alimentos; a integridade intelectual compreenderia a livre expressão do pensamento e o direito autoral lato sensu (do criador de qualquer invento humano); a integridade moral, finalmente, albergaria as liberdades civil, religiosa e política e os direitos à honra, ao recato, ao segredo e à imagem.

Outro ponto muito distante de qualquer zona consensual é o apontamento das principais características desses direitos. De toda forma, interessa destacar para o presente trabalho algumas propriedades como: a generalidade, na medida em que gozáveis por toda e qualquer pessoa; o caráter absoluto, que possibilita a 
oponibilidade a terceiros; o fato de serem inatos, pois acompanham o homem desde o seu nascimento até a sua morte, sem, é claro, esquecer a tutela prevista após o falecimento (art. 12, parágrafo único, art. 14 e art. 20, parágrafo único, todos do CC); a imprescritibilidade, já que a ausência do exercício não implica perda de um direito de personalidade; a extrapatrimonialidade, porquanto não são passíveis de mensuração pecuniária; e, ao término, deixada propositadamente como último atributo a se delinear, a disponibilidade relativa dos direitos da personalidade, malgrado irrenunciáveis e intransmissíveis a princípio (art. 11 do CC), já que podem em certa margem de variabilidade ser mais ou menos mitigados por ato deixado ao arbítrio do próprio titular.

Não por outro motivo, aduz-se que as regras voltadas ao disciplinamento dos direitos da personalidade se justificam não só para a preservação do mínimo existencial e para a reparação de lesões a referidos direitos, mas também - e aqui, de fato, o que é crucial para esta argumentação - para a instrumentalização da autonomia privada, possibilitando o chamado exercício positivo dos direitos da personalidade. ${ }^{36}$

Deveras, o que se quer criticar ao empregar-se recurso de linguagem no próprio título deste tópico ao mencionar-se a "(in)disponibilidade relativa" é tentar romper com uma concepção tradicional e em certo grau reducionista de que os direitos da personalidade são indisponíveis. ${ }^{37}$ Ao contrário, seguindo-se um pensamento de individualismo moderado (BORGES, op. cit., p. 107), salienta-se, em caráter conclusivo, que a disponibilidade dos direitos da personalidade há de ser encarada positivamente, como criadora de uma esfera privada que esteja imune a cerceamentos provenientes de um ente público ou de um agente privado, sendo assim o locus abstrato propício ao exercício da liberdade jurídica do indivíduo.

\section{A interação dos direitos da personalidade com a teoria da eficácia horizontal dos direitos fundamentais}

Desde o caso Lüth (BVerfGE 7, 198-230) ${ }^{38}$, na Alemanha, muito se discute sobre a eficácia horizontal dos direitos fundamentais, que nada mais é do que a aplicabilidade dos direitos fundamentais na relação

\footnotetext{
${ }^{36}$ Quando Roxana Borges (op. cit., p. 103) se refere ao exercício positivo, utiliza este adjetivo para criar uma dicotomia com a chamada tutela negativa dos direitos da personalidade, a qual se destina à salvaguarda desses mesmos direitos contra lesões do Estado e de terceiros particulares, ou seja, à criação de uma esfera de proteção contra intromissões indevidas.

${ }^{37} \mathrm{Na}$ realidade, pouco importa a nomenclatura, devendo-se entender como mera preferência do hermeneuta a utilização da indisponibilidade ou da disponibilidade, contanto que ambas sejam imediatamente adjetivadas de relativa, pois este qualificativo, sim, demarca fortemente a plausibilidade em admitir-se uma esfera própria de exercício da liberdade individual sobre os direitos da personalidade, não significando, na outra extremidade, pregar o puro arbítrio subjetivo, uma vez que o Estado há de intervir para estabelecer certos limites a esses atos de disposição. Isso pode ser exemplificado pela eutanásia e pela ortotanásia, já que ilustram bem a fronteira existente hodiernamente no Brasil ao exercício da autonomia privada: admite-se ao particular a escolha pela segunda, porém ainda se criminaliza a conduta daquele que pratica a primeira. Independentemente dos juízos de valor que caberão em etapa derradeira do trabalho, em termos dogmáticos este caso demonstra uma intervenção estatal no balizamento da disponibilidade do direito à vida, tudo a corroborar a variabilidade ora propugnada.

${ }^{38} \mathrm{O}$ caso envolvendo Eric Lüth diz respeito à lide formada entre este judeu, então Presidente do Clube da Imprensa, e o diretor Veit Harlan, produtor de cinema que havia participado de filme antissemita durante o regime hitlerista. O primeiro organizou um
} 
particular-particular, concretizada em estágio mais amadurecido da teoria, se confrontada com a tradicional perspectiva vertical, que via nesses direitos um feixe protetivo individual para repelir as investidas estatais.

Pensou-se em trazer a indicada teoria da eficácia horizontal para se questionar a viabilidade em ainda se cogitar em direitos da personalidade em casos como o da morte digna e do prolongamento artificial da vida, haja vista a coincidente natureza jurídica de boa parte dos direitos em questão, ora abordados como fundamentais, ora como próprios da personalidade.

Essa sobreposição de ideias fez com que se advogasse academicamente a inocuidade da mantença na distinção das duas categorias, observando-se, contudo, que o rol de direitos fundamentais é mais extenso do que aquele de direitos da personalidade, de forma que os primeiros formam um conjunto englobante destes últimos (FACHIN; PIANOVSKI, op. cit., p. 13).

Na contramão, há quem trilhe outra linha de pensamento - com a qual se concorda -, advertindo que os direitos da personalidade, historicamente concebidos em estágio precedente à teoria dos direitos fundamentais, devem, sim, ser utilizados como ferramenta para resolução de conflitos entre particulares no âmbito do Direito privado, o que, por termos diversos, implica reconhecer a prescindibilidade da eficácia horizontal na tentativa de oferecer soluções práticas a casos civis intrincados, como os da eutanásia, da ortotanásia e da distanásia.

Outro debate que, por outro lado, parece não ter tanta intensidade no Brasil diz respeito, ainda no tema da eficácia horizontal, se ela seria imediata (direta) ou mediata (indireta): na primeira hipótese, a incidência da norma de direito fundamental sobre a situação de fato é automática, ao passo que, na segunda, exige-se uma interposição legislativa que funcione como um liame entre o texto constitucional e a realidade fática ${ }^{39}$.

Não convém alongar-se demasiadamente nessa discussão, mas é importante frisar que no Brasil o próprio STF já teve a oportunidade de reconhecer a eficácia horizontal imediata em Recurso Extraordinário (RE) levado ao tribunal em virtude de suposta violação ao direito fundamental da ampla defesa e à garantia do contraditório de sócio excluído de sociedade civil sem fins lucrativos. ${ }^{40} \mathrm{~A}$ verdade é que, diante da ordem

boicote ao novo filme de Harlan, denunciando o comportamento do produtor cinematográfico durante o nazismo, tendo, ao final, sucesso na empreitada. Diante do fracasso, Harlan ajuizou uma ação exigindo a reparação pelos prejuízos. Embora tivesse inicialmente sido bem sucedido no intento, com a chegada da demanda ao Tribunal Constitucional Federal, entendeu a corte que havia, no caso, a aplicação dos direitos fundamentais na relação jurídica entre os particulares, com o intuito de dar prevalência à liberdade de expressão de Eric Lüth, evidenciando-se portanto o vasto alcance de aplicabilidade desses direitos, sem restringi-los às relações entre indivíduo e Estado.

${ }^{39}$ Canaris (2003, p. 53-4) se opõe à aplicação imediata, explicando as dificuldades que isso ocasionaria, por exemplo, em casos relativos a responsabilidade civil e contratos. Assim, consoante elucidação fornecida pelo próprio autor, uma nulidade contratual poderia perfeitamente violar direito fundamental e isso inverteria toda a lógica do sistema civilista. Por outro lado, em solo brasileiro, parece que o art. $5^{\circ}, \$ 1^{\circ}$, da CRFB explicita um comando que impõe ao hermeneuta a observância da aplicação imediata. ${ }^{40}$ BRASIL. Supremo Tribunal Federal, 2a Turma. "EMENTA: SOCIEDADE CIVIL SEM FINS LUCRATIVOS. UNIÃO BRASILEIRA DE COMPOSITORES. EXCLUSÃO DE SÓCIO SEM GARANTIA DA AMPLA DEFESA E DO CONTRADITÓRIO. EFICÁCIA DOS DIREITOS FUNDAMENTAIS NAS RELAÇÕES PRIVADAS. RECURSO DESPROVIDO. I. EFICÁCIA DOS DIREITOS FUNDAMENTAIS NAS RELAÇÕES PRIVADAS. As violações a direitos 
constitucional pátria, esse ponto de vista se mostra, em tese, inescapável, tendo-se em vista o preceituado pelo art. $5^{\circ}, \mathbb{\$} 1^{\circ}, \mathrm{da}$ CRFB.

Em suma, o que se pode deduzir desta breve divagação é que a categoria dos direitos da personalidade é, sem dúvidas, pertinente e aproveitável para a discussão sobre liberdade e morte digna, porém isso não implica recusar a envergadura constitucional dos valores positivados no ápice do sistema, tais como a dignidade da pessoa humana e a autonomia privada. Logo, cabe ao hermeneuta ter a habilidade de lançar mão de ambas as figuras jurídicas disponíveis como forma de enriquecer uma discussão que não pode se reduzir apenas às questões teoréticas formalistas.

\section{A insuficiência dos artigos do código civil}

Encerradas essas observações relativas aos direitos da personalidade, desce-se definitivamente à análise ao plano da legislação civil, especificamente do CC de 2002.

Com a personificação do Direito civil, posta em desenvolvimento principalmente a partir da CRFB, abriu-se mão do vetusto modelo patrimonialista presente no Código Beviláqua, notando-se, com o advento do Código de Reale, a mudança axiológica evidenciada na própria organização dos dispositivos da Parte Geral. Desse

fundamentais não ocorrem somente no âmbito das relações entre o cidadão e o Estado, mas igualmente nas relações travadas entre pessoas físicas e jurídicas de direito privado. Assim, os direitos fundamentais assegurados pela Constituição vinculam diretamente não apenas os poderes públicos, estando direcionados também à proteção dos particulares em face dos poderes privados. II. OS PRINCÍPIOS CONSTITUCIONAIS COMO LIMITES À AUTONOMIA PRIVADA DAS ASSOCIAÇÕES. A ordem jurídico-constitucional brasileira não conferiu a qualquer associação civil a possibilidade de agir à revelia dos princípios inscritos nas leis e, em especial, dos postulados que têm por fundamento direto o próprio texto da Constituição da República, notadamente em tema de proteção às liberdades e garantias fundamentais. O espaço de autonomia privada garantido pela Constituição às associações não está imune à incidência dos princípios constitucionais que asseguram o respeito aos direitos fundamentais de seus associados. A autonomia privada, que encontra claras limitações de ordem jurídica, não pode ser exercida em detrimento ou com desrespeito aos direitos e garantias de terceiros, especialmente aqueles positivados em sede constitucional, pois a autonomia da vontade não confere aos particulares, no domínio de sua incidência e atuação, o poder de transgredir ou de ignorar as restrições postas e definidas pela própria Constituição, cuja eficácia e força normativa também se impõem, aos particulares, no âmbito de suas relações privadas, em tema de liberdades fundamentais. III. SOCIEDADE CIVIL SEM FINS LUCRATIVOS. ENTIDADE QUE INTEGRA ESPAÇO PÚBLICO, AINDA QUE NÃO-ESTATAL. ATIVIDADE DE CARÁTER PÚBLICO. EXCLUSÃO DE SÓCIO SEM GARANTIA DO DEVIDO PROCESSO LEGAL.APLICAÇÃO DIRETA DOS DIREITOS FUNDAMENTAIS À AMPLA DEFESA E AO CONTRADITÓRIO. As associações privadas que exercem função predominante em determinado âmbito econômico e/ou social, mantendo seus associados em relações de dependência econômica e/ou social, integram o que se pode denominar de espaço público, ainda que não-estatal. A União Brasileira de Compositores - UBC, sociedade civil sem fins lucrativos, integra a estrutura do ECAD e, portanto, assume posição privilegiada para determinar a extensão do gozo e fruição dos direitos autorais de seus associados. A exclusão de sócio do quadro social da UBC, sem qualquer garantia de ampla defesa, do contraditório, ou do devido processo constitucional, onera consideravelmente o recorrido, o qual fica impossibilitado de perceber os direitos autorais relativos à execução de suas obras. A vedação das garantias constitucionais do devido processo legal acaba por restringir a própria liberdade de exercício profissional do sócio. $\mathrm{O}$ caráter público da atividade exercida pela sociedade e a dependência do vínculo associativo para o exercício profissional de seus sócios legitimam, no caso concreto, a aplicação direta dos direitos fundamentais concernentes ao devido processo legal, ao contraditório e à ampla defesa (art. 5\%, LIV e LV, CF/88). IV. RECURSO EXTRAORDINÁRIO DESPROVIDO”. RE 201.819-RJ. Recorrente União Brasileira de Compositores (UBC). Recorrido Arthur Rodrigues Villarinho. Relatora: Ministra Ellen Gracie. Relator para acórdão: Ministro Gilmar Mendes. Brasília, 11 outubro 2005 . 
modo, previu-se entre os arts. 11 e 20 uma disciplina própria para os direitos da personalidade, bastante significativa do protagonismo adquirido pelas questões ligadas à pessoa, com a ordenação normativa das matérias patrimoniais em etapa posterior.

No tocante à morte digna, o único dispositivo legal que se aproximou do assunto foi o art. 15, que nitidamente não atende nem um pouco aos problemas enfrentados no desenho dos limites ao objeto do testamento biológico, pois direcionado para os casos das chamadas cirurgias (ou tratamentos) de alto risco, nas quais o paciente tem uma expressiva chance de falecer por força da intervenção médica.

Ainda assim - e neste ponto começa-se justamente a adentrar as questões iniciais relativas às diretivas antecipadas -, não há motivos para que uma suposta lacuna no disciplinamento dessa figura, que basicamente é instrumental à disposição de direito de personalidade, mais propriamente o direito à vida, sirva de obstáculo ao reconhecimento da conformidade de referida manifestação de vontade com o Direito brasileiro.

Deveras, como se raciocinará a seguir, mesmo que não houvesse uma regulamentação infralegal providenciada pelo Conselho Federal de Medicina (CFM), poder-se-ia lidar com todos os entraves mediante o uso dos recursos teóricos fornecidos pela teoria geral do negócio jurídico.

\section{Esclarecimentos semânticos: eutanásia, ortotanásia e distanásia}

Antes, entretanto, de ingressar-se na última seção, integralmente dedicada ao testamento biológico sob uma leitura jurídico-dogmática, é imprescindível distinguir semanticamente expressões doravante muito citadas no curso do texto, haja vista o objeto de referida declaração.

Dessarte, refere-se aqui especificamente aos termos eutanásia, ortotanásia e distanásia.

A eutanásia consiste no ato interventivo de causar morte sem sofrimento a um paciente em estágio terminal, ou portador de doença incurável provocadora de intensas dores, ou, ainda, em situação de inconsciência permanente e irreversível (ALVES, 2013, p. 267). Esta conduta é atualmente criminalizada pelo art. 121, \$1º do Código Penal (CP), que tipifica a figura do homicídio privilegiado, de forma a consubstanciar causa de diminuição da pena, de acordo com a valoração realizada à época varguista.

A ortotanásia, ao revés, é o comportamento de abstenção de qualquer intervenção médica no prolongamento da vida de uma pessoa, propiciando ao paciente uma morte conforme o curso causal natural da doença ou incapacitação que o aflige. ${ }^{41}$

\footnotetext{
${ }^{41}$ Cristiane Avancini Alves (op. cit., p. 267) assim expõe: "Importante ressaltar a diferenciação de termos: a ortotanásia caracterizase pelo respeito à decisão do paciente em fase terminal, de enfermidade grave e incurável, de limitar ou suspender procedimento e/ou tratamento que prolonguem sua vida, sendo garantidos os cuidados necessários quanto a uma assistência integral, enquanto que as diretivas antecipadas de vontade tratam de decisão realizada em estado anterior de enfermidade, no caso em que, verificada ou ocorrida essa enfermidade, o paciente se encontre em estado de inconsciência, não podendo manifestar sua vontade de forma
} 
Por fim, a distanásia configura a intervenção que visa ao prolongamento artificial da vida de um paciente, acentuando a lentidão no curso das circunstâncias vitais que o levariam ao óbito se não fossem as medidas paliativas prorrogadoras. ${ }^{42}$

Como enfatizado há pouco, as definições acima apresentadas serão de imensa valia na delimitação do conteúdo do testamento biológico e, por isso, entendeu-se oportuno esclarecê-las antes de principiar-se a última parte deste trabalho, o que se faz a seguir, em vista de breves comentários generalizantes sobre os negócios jurídicos.

\section{"A PONTE DOGMÁTICA": A MORTE DIGNA A LUZ DA TEORIA GERAL DO NEGÓCIO JURÍDICO}

\section{Histórico e terminologia}

Como o subtítulo já sugere ao leitor, após a detida análise de vieses filosófico e normativoprincipiológico acerca dos valores que fundam o debate concernente à morte digna, pretende-se doravante utilizar a categoria do negócio jurídico para operacionalizar o testamento biológico em termos jurídico-dogmáticos, o que, em síntese, explica a figura de linguagem escolhida para relevar a transição de perspectiva nesta linha de raciocínio. Contudo, antes disso, ainda cabem mais alguns comentários concisos de cunho terminológico, os quais não deixam de ser concomitantemente de índole histórica.

Assim, a figura popularmente conhecida como testamento biológico foi pioneiramente elaborada pelo humanista norte-americano Luis Kutner (ANDORNO, 2012, p. 77), no ano de 1968, que the atribuiu o nome de living will, expressão de difíil tradução para os idiomas derivados do tronco latino, tendo-se em mente o aspecto polissêmico do substantivo wil ${ }^{\text {³}}$, que, aliás, também pode ser utilizado como verbo, no sentido de "desejar". Se, porém, retidos à morfologia substantiva, a expressão pode ser traduzida como testamento, determinação, vontade,

\footnotetext{
livre e autônoma. Ainda, fundamental não confundir ambas as situações, que enaltecem e efetivam a autonomia e a beneficência de tratamento, bem como a ética médica, com a prática de eutanásia, que se constitui em indução, com intenção, a óbito, com a autorização consciente da pessoa que passa por determinado tipo de sofrimento, não necessariamente em estado terminal”.

${ }^{42}$ Houaiss (op. cit.) indica o sentido de "morte lenta, com grande sofrimento", observando-se, quanto à etimologia, referir-se o prefixo "dis" à privação ou à dificuldade, enquanto "tanásia" decorre de thánatos, termo expressivo de "morte, pena de morte", podendo-se também apontar a palavra dusthánatos, significativa daquilo "que tem morte penosa, lenta”. Eutanásia, por sua vez, decorre de euthanasia, a qual quer dizer "morte sem sofrimento". Ortotanásia, finalmente, tem prefixo decorrente do termo grego orthos, exprimindo a adjetivação de direito, preciso, reto, exato - portanto, seria a "morte correta".

${ }^{43}$ Esses significados são extraídos do dicionário Merriam-Webster (2016), que também aponta a etimologia do termo anglo-saxão: "Origin of will: Middle English (1st \& 3d singular present indicative), from Old English wille (infinitive wyllan); akin to Old High German wili (3d singular present indicative) wills, Latin velle to wish, will. First Known Use: before 12th century”.
} 
sentimento. Living, ao contrário, é adjetivo de espectro semântico bastante reduzido, denotando presença de vida, vivo, ativo. ${ }^{44}$

Em meio a essa confusão semântica, as traduções para outras ordens jurídicas foram as mais variadas possíveis. Na França, por exemplo, universalizou-se o termo testament de vie, logo, testamento de vida; na Espanha, optou-se por instrucciones previas; em Portugal e no Brasil, enfim, disseminou-se a locução testamento vital - e, em menor reiteração, testamento biológico.

No entanto, com o amadurecimento do assunto entre os juristas pátrios, iniciaram-se várias críticas à expressão traduzida do inglês, com irrefutáveis argumentos técnicos para respaldá-las. Assim, argumentou-se que o testamento propriamente dito, figura prevista e disciplinada minuciosamente no Livro V - Do Direito das Sucessões do CC, configura negócio jurídico unilateral cuja eficácia é causa mortis, isto é, cujos efeitos só se deflagram a partir do falecimento do testador, normalmente tendo objeto eminentemente patrimonial, embora nada impeça disposições de natureza diversa (ALVES, op. cit., p. 266). De outro lado, o chamado testamento vital é formulado com o intuito de projetar seus efeitos ainda em vida - eficácia inter vivos - do declarante, porém em instante no qual ele não tenha mais condições de lucidamente externar sua declaração de vontade.

Redundando dessa crítica, nasce a expressão "instruções prévias", semelhantemente à opção espanhola, ou, uma das mais preferidas no Brasil pelos críticos da terminologia primitiva, "diretivas antecipadas de vontade", sendo esta última inegavelmente muito expressiva do conteúdo e do momento em que a declaração é exarada.

Ainda assim, embora se curve à tecnicidade da expressão "diretivas antecipadas de vontade", entende-se que não há obstáculos à utilização de sinonímias, nem mesmo da original locução testamento vital, nomenclatura que, diga-se de passagem, popularizou o instituto no Direito nacional. Essa asserção se justifica na medida em que o nomen juris em nada influencia a verdadeira natureza jurídica de uma dada categoria, representando um mero rótulo de evocação da figura tratada, sem que diferentes termos sirvam para desnaturá-la.

Por esses motivos, portanto, explica-se o uso irrestrito neste trabalho das diversas expressões cunhadas no português, na medida em que não prejudicam em nada o entendimento do assunto. Deveras, julga-se mais importante o correto desenho técnico-abstrato, pois este, sim, será crucial para esquadrinhar o regime jurídico do instituto.

\footnotetext{
${ }^{44}$ Conforme Black's Law Dictionary (2009, p. 1018): "living will. (1972) An instrument, signed with the formalities statutorily required for a will, by which a person directs that his or her life not be artificially prolonged by extraordinary measures when there is no reasonable expectation of recovery from extreme physical or mental disability. Most states have living-will legislation. - Also termed declaration of a desire for a natural death; directive to physicians". Noutro trecho (Ibid., p. 60), o dicionarista explana o sinônimo advance directive: "(1984) 1. A document that takes effect upon one's incompetency and designates a surrogate decision-maker for healthcare matters. The Uniform Health-Care Decision Act (1993) states that the power of attorney for healthcare must be in writing and signed by the principal. Unless otherwise stated, the authority is effective only upon a determination that the principal lacks capacity, and it ceases to be effective once the principal regains his capacity. The agent must make decisions in accordance with the principal's relevant instructions, if there are any, or in the principal's best interests. - Also termed power of attorney for healthcare, healthcare proxy".
} 
Ante as primevas elucidações, dirige-se a atenção nos próximos parágrafos à teoria ponteana do fato jurídico, introduzindo-se rapidamente um panorama das espécies fáticas, com a subsequente análise estrutural do suporte fático de um testamento vital.

\section{Sucintos comentários sobre a teoria do fato jurídico}

No Tratado de Direito Privado, Pontes de Miranda (2012, t. II, p. 253-4) desenvolve a tão difundida teoria do fato jurídico, por meio da qual elabora um quadro classificatório com as espécies de fatos que, recebendo a incidência normativa, saem do mundo fático e ingressam no mundo jurídico, ocasião em que recebem a mesma adjetivação para expressar o suporte fático juridicizado. Em razão do recorte metodológico proposto para o artigo, não será possível distender-se sobre os mais precisos detalhes da teoria, cerceando-se a presente análise à breve exposição das subcategorias componentes do gênero.

Nesse diapasão, o fato jurídico lato sensu há de ser entendido como suporte fático que sofre a incidência da norma, ingressando no mundo jurídico e então produzindo sua eficácia. Conseguintemente, como desdobramentos deste gênero, há o fato jurídico stricto sensu, o ato-fato jurídico e o ato jurídico lato sensu, que, a seu turno, subdivide-se em ato jurídico stricto sensu e em negócio jurídico.

O fato jurídico stricto sensu é um evento da natureza, que não tem no seu suporte fático uma manifestação de vontade do homem, mas nem por isso deixa de ser relevante para o ordenamento, pois são eventos que repercutem na esfera jurídica dos sujeitos de direito. Assim, apenas a título ilustrativo, tanto a morte como o nascimento são fatos jurídicos stricto sensu, que provocam uma multiplicidade de consequências no mundo jurídico, tais como, no primeiro caso, a aquisição de personalidade e a formação dos vínculos familiares e, no segundo, os efeitos sucessórios e previdenciários.

O ato-fato jurídico é espécie que embora tenha no suporte fático uma conduta humana, é recebida pelo ordenamento jurídico independentemente do aspecto anímico-volitivo imanente ao comportamento do homem - a declaração de vontade em si é desprezível para a configuração desse fato jurídico. A despeito da polêmica teórica, apontam-se como exemplos o adimplemento obrigacional, a especificação, a decadência e a prescrição (MELLO, 2008, p. 136-140).

Finalmente, o ato jurídico lato sensu consiste em declaração de vontade que é assim absorvida pela ordem jurídica, ora configurando fato jurídico que tem seus efeitos pré-determinados pelas normas, em contornos enrijecidos - aqui se alude ao ato jurídico stricto sensu, como acontece com o reconhecimento de 
paternidade -, ora revestindo fato jurídico cujos efeitos são moduláveis pela vontade das partes (ou da parte), com o intento de constituir, modificar ou extinguir relação jurídica - por exemplo, o contrato e o testamento. ${ }^{45}$

Posta essa classificação, encerra-se este trecho inicial com a seguinte reflexão: se o testamento tradicional, ou melhor, se o testamento próprio do Direito sucessório, instituto milenar que encontra amparo já no Direito romano ${ }^{46}$, é considerado negócio jurídico unilateral personalíssimo, cujos efeitos são irradiados a partir da morte do testador, parece claro que o testamento vital, ainda que produza efeitos durante a vida do testador, deve ser encarado estruturalmente da mesma forma, portanto, como negócio jurídico unilateral personalíssimo inter vivos. Ora, se o declarante pode, nessas instruções prévias, determinar o conteúdo do ato de maneira relativamente ampla, respeitando, decerto, os limites postos pela ordem jurídica pátria, há então indiscutivelmente um negócio jurídico unilateral sobre o qual pende uma condição suspensiva, a ser implementada caso o declarante ingresse em estado terminal, ou em estado de inconsciência permanente, ou em qualquer outra situação apta a caracterizar estágio de doença incurável acarretadora da morte do paciente.

\section{O panorama: conceito, natureza jurídica, estrutura, espécies e características fundamentais}

Fornecidas essas informações gerais, é possível conceituar o testamento vital como o negócio jurídico extrapatrimonial (ou existencial), unilateral, personalíssimo e sujeito a condição suspensiva, cujo objeto se volta às medidas e aos tratamentos médicos que o declarante deseja receber caso ingresse em estado terminal, ou em situação na qual não possa mais conscientemente externar sua vontade, ou ainda em estágio avançado de doença incurável que o levará à morte - em síntese, eventos que levam ao implemento da condição, deflagrando-se então os efeitos previstos pelo declarante.

Explicando-se, dessarte, alguns componentes dessa conceituação, trata-se de fato jurídico dotado de natureza de negócio jurídico, na medida em que o suporte fático é composto por uma declaração de vontade

\footnotetext{
${ }^{45}$ Pontes de Miranda (op. cit., t. III, p. 55) explica que: "O conceito [de negócio jurídico] surgiu exatamente para abranger os casos em que a vontade humana pode criar, modificar ou extinguir direitos, pretensões, ações, ou exceções, tendo por fito êsse acontecimento do mundo jurídico. Naturalmente, para tal poder fáctico de escolha, supõe-se certo auto-regramento de vontade, dito 'autonomia da vontade', por defeito de linguagem (nomos é lei); com êsse auto-regramento, o agente determina as relações jurídicas em que há de figurar como têrmo" (grifo do autor).

${ }^{46}$ Conforme pesquisa de Max Kaser (1999, p. 368), ao encerrar-se a vida econômica rural no limiar da República, somado ao desenvolvimento da consciência da personalidade, a liberdade de testar passa a ser a regra, de forma a adquirir inclusive a preponderância sobre a sucessão intestada no período indicado. Outrossim, quanto ao objeto, importante ressaltar que desde o Direito romano já era possível incluir disposições não patrimoniais no testamento. Abordagem ainda mais rica é a de Moreira Alves (1980, v. 2, p. 433-4), ao explanar que Ulpiano definia o testamento como "testemunho justo da nossa mente feito de forma solene para que valha depois de nossa morte" e Modestino, a seu turno, explicava-o como "a justa expressão da nossa vontade a respeito daquilo que cada qual quer que se faça depois de sua morte". Na etimologia dos juristas romanos, enfim, testamentum se origina de testatio mentis, que significa "testemunho da vontade". Entretanto, Moreira Alves entende que todos esses conceitos não caracterizam a essência do instituto à época da civilização romana, voltado eminentemente à instituição de herdeiro - por conseguinte, a proposta conceitual do romanista brasileiro é esta: "No direito romano, testamento éo ato solene de uíltima vontade que contém a instituição de herdeiro" (grifo do autor).
} 
modulada pelo próprio testador, albergando um conteúdo peculiar, de forma a emanar as consequências somente na hipótese de ocorrer um evento que o impossibilite, a partir da concretização, de manifestar conscientemente sua vontade. Em seguida, a adjetivação extrapatrimonial se justifica em razão da ausência de base econômica no objeto do negócio, porquanto se dirige exclusivamente à maneira como será tratado e às eventuais intervenções médicas obstadas ou requeridas para a ocasião de inconsciência ou incapacidade de fato.

Ademais, é unilateral e personalíssimo porque, em primeiro lugar, há apenas um centro de imputação de interesses, que é o do próprio declarante (testador), e, em segundo lugar, porque inexiste a possibilidade de outrem externar similar declaração em nome e no interesse daquele que receberá os tratamentos futuros. Como se não bastasse, há que se salientar a revogabilidade - a retirada da vox, afetando diretamente o suporte fático - da declaração enquanto persistir a plena capacidade civil do paciente, pois seria absolutamente iníquo prendê-lo permanentemente ao que declarou num passado remoto ou próximo, nada impossível diante de uma eventual mudança de sua valoração da vida ou da saúde.

Da perspectiva estrutural, apresentam-se os elementos de existência gerais intrínsecos: forma, objeto e circunstâncias negociais. ${ }^{47}$

A primeira é o revestimento que a declaração do testador biológico deve tomar, necessariamente devendo ser escrita, haja vista a importância e os desdobramentos que lhe sucedem. Observe-se, neste ponto, que há autores como Luciana Dadalto (2013, p. 5) restringindo a confecção das diretivas antecipadas de vontade à lavratura de escritura pública, pois, graças à intervenção do tabelião de notas, este seria o instrumento mais seguro para a preservação da escorreita revelação da vontade. ${ }^{48}$

No entanto, não se veem óbices à utilização de instrumento particular, ou até mesmo de certa formalidade que se assemelhe ao testamento cerrado, contanto que previstas em legislação as diversas formas de recobrir o ato lato sensu declarado, em linha analógica à do testamento tradicional. De fato, pense-se, por exemplo,

\footnotetext{
${ }^{47}$ Neste trabalho, adotam-se os elementos de existência indicados por Junqueira de Azevedo (2002, p. 32-4). Há, ainda, os elementos gerais extrínsecos, consistentes em agente, tempo e lugar, sobre os quais não se debruçará no corpo do texto em razão do recorte metodológico realizado. De toda forma, o que se aclara é a presença constante desses elementos extrínsecos, ainda que local e tempo raramente venham acompanhados de requisitos de validade, porém de imensa relevância para identificação espacialcronológica do negócio, costumeiramente demarcados na lavratura do instrumento.

${ }^{48}$ Não se menospreza aqui a consecução da segurança jurídica e da cristalização de fatos no tempo por prova robusta, produzida por tabelião de notas, dotado de fé pública nas declarações que exarar no tocante a fatos que tenham ocorrido à sua presença (BRANDELLI, 2011, p. 255-7). No entanto, assim como o testamento tem três formas muito bem definidas em lei, parece que, mesmo diante da lacuna legal - em oposição, portanto, à argumentação sustentada por Luciana Dadalto na nota de rodapé anterior -, não há motivos para impor única e exclusivamente a lavratura por escritura pública, haja vista o princípio da liberdade de formas. Outrossim, de lege ferenda, também não se vê razão para delimitar em diploma legal a confecção das instruções prévias apenas ao instrumento público lavrado em livro de notas.
} 
na elaboração de um instrumento ${ }^{49}$ particular, acompanhado de três testemunhas (art. 1.876, $\mathbb{S} 1^{\circ}$, do CC), ao final registrando-o no ofício de registro de títulos e documentos que tenha poderes sobre a circunscrição de domicílio do declarante, ainda que o faça para buscar o mero efeito de conservação previsto no art. 127, VII, da Lei dos Registros Públicos (LRP).

Ademais, não se entende admissível a inserção dessas declarações de cunho existencial em testamento tradicional do Direito das sucessões, em razão da incompatibilidade eficacial de ambos os negócios: enquanto as diretivas produzem efeitos inter vivos, o testamento projeta sua eficácia causa mortis, de modo que, neste caso, as consequências pretendidas pelo declarante ficariam retidas, não tendo nenhuma utilidade para o testador no momento em que pudessem se verificar no plano da eficácia (DADALTO, op. cit., p. 7). Tem-se a impressão de ser este o motivo de levar certos autores a afirmar que é vedada a inserção de disposições patrimoniais nas diretivas antecipadas, ou de embaralhá-las em meio a outras declarações, por exemplo, no bojo de uma escritura declaratória de união estável (Ibid, p. 7).

O objeto, a seu turno, é o conteúdo da declaração, consistente sinteticamente nas disposições apostas no instrumento pelo testador. Aqui, naturalmente, as cláusulas se caracterizam pelo caráter extrapatrimonial, isto é, pela ausência de expressão ou de possibilidade em conversão monetária, já que dizem respeito ao zelo, ou ao especial tratamento previamente almejado pelo paciente, que, de maneira prospectiva, projeta seu intento para um fortuito e dramático momento em seu destino.

Importante, contudo, enfatizar o quão essencial é o aconselhamento médico prévio - ou seja, antes da elaboração do instrumento -, pois mediante substanciosas informações advindas de um profissional habilitado, o paciente terá mais condições de fazer uma análise das circunstâncias que poderão envolvê-lo, ciente, portanto, das consequências que podem provir de cada escolha realizada no documento conservatório das diretivas antecipadas. ${ }^{50}$

No Brasil, o único instrumento normativo a auxiliar o intérprete a conferir certos contornos às instruções prévias é a Resolução n. ${ }^{\circ}$ 1.995/2002 do Conselho Federal de Medicina (CFM), cuja validade já foi defendida em âmbito doutrinário (SALGADO, op. cit., p. 94) e judicial. ${ }^{51}$ Tomando-a como ponto de partida, ao conceituar o

\footnotetext{
${ }^{49}$ Ao utilizar-se a expressão "instrumento", deixa-se claro desde já o emprego compatível semanticamente com a técnica processual, que o trata como documento elaborado especificamente com a finalidade de fazer prova futura do ato nele retratado (SANTOS, 2011 , v. 2, p. 434-5).

${ }^{50}$ Fabiana Salgado (2014, p. 130) aduz que, no âmbito do direito médico, opta-se pelo emprego da expressão consentimento informado como figura que mais se aproxima da ideia de autonomia privada do paciente. Nesta relação entre médico e paciente, o primeiro deve fornecer todas as informações técnicas que estão fora da zona cognitiva do atendido, a fim de que este último esteja subsidiado do maior número de dados possível na tomada de uma decisão bem amparada, de forma a estabelecer não só a recusa ou a aceitação, mas também os limites da intervenção médica, quando for o caso.

${ }^{51}$ BRASIL. Justiça Federal, Seção Judiciária do Estado de Goiás, Primeira Vara de Goiânia. Sentença com pedidos julgados improcedentes. Ação Civil Pública, Processo n. ${ }^{\circ}$ 1039-86.2013.4.01.3500/Classe: 7100. Requerente: Ministério Público Federal. Requerido: Conselho Federal de Medicina. Juiz Federal Substituto Eduardo Pereira da Silva. Goiânia, 21 fev. 2014.
} 
vertente negócio no art. 10,52 o objeto se delimita aos desejos sobre cuidados e tratamentos que o paciente pretende receber ou evitar no momento de incapacitação de expressar sua vontade.

Deveras, muito difícil, ao tratar-se do objeto, não aproveitar o ensejo para aglutinar as questões atinentes à sua validade, que consiste em verificar, no plano adjetivo, se é lícito, determinado ou determinável (art. 104, II, do CC). Para tanto, há algumas observações que podem ser feitas com fundamento na escassa normatização vigente, além de comentários conjecturais de escopo teórico-investigativo.

Limita-se, no entanto, o conteúdo aos preceitos indicados no Código de Ética Médica, nos termos do art. $2^{\circ}$, $\mathbb{1} 2^{\circ}$, da Resolução n. ${ }^{\circ}$ 1.995/2002 do CFM, vedando-se, outrossim, a disposição acerca de transplantes de órgãos, uma vez que a Lei de Transplantes (Lei n. ${ }^{\circ}$ 9.434/97) reserva ao cônjuge ou ao parente maior até o segundo grau o poder de decisão, com a atestação de testemunhas que estiveram presentes no momento de verificação da morte. ${ }^{53}$

Ainda na tentativa de estabelecer sólidas fronteiras à declaração de vontade do testador vital, parece muito adequada a previsão de lapso temporal de eficácia para as diretivas, assim como estabelece a legislação lusitana - vista com um pouco mais de detalhes na próxima seção -, permitindo-se, porém, a confirmação tecnicamente esta expressão se reserva para se convalidarem os negócios anuláveis, daí a necessidade de compreendê-la em sentido muito largo, talvez atécnico - com o intuito de renová-lo. Realmente, a demarcação de tempo é fator a ser cogitado diante da constante evolução científico-tecnológica no campo da medicina, o que faz lembrar a expressão "estado da técnica", comumente empregada no Direito regulador da propriedade industrial para referir-se às informações que já eram de conhecimento geral antes do pedido de registro da patente.

Realmente, essa expressão tem um poder semântico que pode ser aproveitado no presente caso: o paciente pode dispor em determinado sentido porque, à época em que externada tal declaração, a ciência médica não tinha tratamento eficaz para a determinada moléstia acometedora do seu discernimento. Entretanto, no momento em que já incapacitado, tendo o médico de seguir as orientações antecipadamente exaradas, se houver uma nova descoberta nas ciências médicas imprevista originariamente pelo paciente, seria um equívoco abissal coagir o primeiro a obedecer àquelas diretivas descompassadas com a nova realidade técnico-científica.

\footnotetext{
${ }^{52}$ Art. $1^{\circ}$. Definir diretivas antecipadas de vontade como o conjunto de desejos, prévia e expressamente manifestados pelo paciente, sobre cuidados e tratamentos que quer, ou não, receber no momento em que estiver incapacitado de expressar, livre e autonomamente, sua vontade.

${ }^{53}$ Art. 4º. A retirada de tecidos, órgãos e partes do corpo de pessoas falecidas para transplantes ou outra finalidade terapêutica, dependerá da autorização do cônjuge ou parente, maior de idade, obedecida a linha sucessória, reta ou colateral, até o segundo grau inclusive, firmada em documento subscrito por duas testemunhas presentes à verificação da morte. (Redação dada pela Lei $n^{\circ}$ 10.211, de 23.3.2001). Art. 5. A remoção post mortem de tecidos, órgãos ou partes do corpo de pessoa juridicamente incapaz poderá ser feita desde que permitida expressamente por ambos os pais, ou por seus responsáveis legais. Art. $6^{\circ}$. É vedada a remoção post mortem de tecidos, órgãos ou partes do corpo de pessoas não identificadas.
} 
Embora não se trate de invalidação do negócio jurídico, na medida em que esta é estática - examinada no exato instante em que o suporte fático ingressa no mundo jurídico -, consequentemente descabendo cogitar em exame futuro, tem-se a impressão de que a melhor saída do ponto de vista teorético, nessa mesma hipótese de inovação do estado da técnica, é considerar o negócio jurídico ineficaz, por inexistir implemento da condição predisposta como elemento de existência acidental. ${ }^{54}$

Posto isso, basta pensar-se que o século XX é por muitos chamados de século do cérebro, graças aos avanços conquistados pelas neurociências, para se concluir, de lege ferenda, pela necessidade de relativizarem-se temporalmente as diretivas antecipadas, nada obstando sua renovação ao chegar-se próximo do exaurimento do período pré-fixado em regra legal..$^{55}$

Em suma, pondo-se fim às digressões acima, os limites às declarações devem ser buscados no ordenamento jurídico como um todo, e não apenas na comentada resolução médica, o que parece esbarrar principalmente na norma penal impeditiva da eutanásia (art. 121, $\$ 1^{\text {o }}$, do CP), obstando-se, noutras palavras, que o paciente consigne no testamento biológico a intervenção médica com o intuito de abreviar ou acelerar o processo natural em direção ao óbito. Realmente, diante de exame rigorosamente legal, não cabe ao intérprete outra solução hermenêutica, salvo a promulgação da lei que tenha por finalidade alterar o comentado artigo para descriminalizar a eutanásia. ${ }^{56}$ Todavia, embora o operador do Direito esteja pautado por essas balizas, deixa-se para discutir nas notas conclusivas se a proibição da eutanásia é causa para afirmar-se a inexistência de morte digna no Brasil.

Por fim, o terceiro elemento existencial se consubstancia nas circunstâncias negociais, as quais são tratadas como o acervo de elementos fáticos que traduzem a terceiros - in casu, principalmente ao corpo clínico integrado de médicos e enfermeiros - em interação com o declarante o objetivo de conferir efeitos jurídicos às disposições extrapatrimoniais por ele externadas antecipadamente - portanto, uma manifestação de vontade que, em razão de um quadro sociocultural, é interpretada pela coletividade como produtora de consequências no mundo jurídico (JUNQUEIRA DE AZEVEDO, op. cit., p. 124).

\footnotetext{
${ }^{54}$ Requisito de validade não pode ser, haja vista a usual afirmação conforme a qual o plano da validade é uma fotografia que deve ser vista no instante em que o suporte fático ingressa no mundo jurídico; muito menos elemento de existência, pois o suporte fático completo do testamento vital já ingressou no mundo jurídico.

${ }^{55}$ Diferente será, sem dúvida, se o paciente deixar bem claro nas disposições das diretivas antecipadas que, mesmo se houver inovação do estado da técnica, preferirá não receber determinada intervenção médica, embora neste caso possa se verificar um embate com os preceitos do Código de Ética Médica (art. 2º $\$ 2^{\circ}$, da Resolução n.o 1.995/2012).

${ }^{56}$ Houve um antigo Projeto de Lei n. 125/96, proposto pelo então Senador da República Gilvam Borges (PMDB-AP), arquivado, contudo, ao final da legislatura, tendo-se em vista a polêmica ínsita ao tema. No projeto, previa-se a possibilidade de prática da eutanásia em hipóteses delimitadas, com a exigência de cinco médicos atestando a desvalia na mantença do sofrimento do paciente, porém sempre a pedido deste último ou de seus parentes, caso o primeiro não pudesse mais fazê-lo. Todavia, discorda-se deste projeto no tocante à autorização para que os pais possam assim também decidir. Parece que o mais prudente é fiar-se tão somente na vontade declarada e devidamente comprovada do próprio paciente, por isso defender-se veementemente as diretivas antecipadas.
} 
Quanto aos elementos de existência categoriais, preliminarmente se ressalta não derivarem da vontade do declarante, mas, ao contrário, no caso específico das diretivas antecipadas, principalmente da doutrina e, na ordem nacional, da Resolução n. ${ }^{\circ}$ 1.995/2002 do CFM. Consoante doutrina abraçada neste texto, subdividem-se em essenciais (ou inderrogáveis) e naturais (ou derrogáveis) (Ibid., p. 35). Os primeiros são aqueles inafastáveis pelo testador, pois se assim pudesse fazê-lo estaria desnaturando a própria essência das instruções prévias; os segundos, ao contrário podem ser repugnados pelo declarante sem que isso interfira na tipologia negocial.

Materializa-se essa dicotomia mormente na análise das espécies de diretivas antecipadas de vontade, pois, ao confrontá-las pelo esboço de um quadro geral, nota-se exatamente a presença de elementos que se repetem em todas elas - logo, essenciais ou inderrogáveis - e de outros que lhes são privativos, estes últimos, sim, categoriais derrogáveis ou naturais.

Dessarte, a corroborar o que se asseverou acima, apontam-se como espécies de diretivas antecipadas (advance directives), à luz do que se desenvolveu no Direito norte-americano com base no Patient SelfDetermination Act, de $1^{\circ}$ de dezembro de 1991: o living will, que é a declaração de vontade para cuidados futuros em situação de incapacidade; o durable power of attorney for health care, que é o mandato duradouro cujo objeto confere poderes prospectivos a um representante, com o intuito de outorgar-lhe o poder de tomar as decisões sobre cuidados médicos na ocasião de incapacidade do paciente; o advance care medical directive, consistente em decisão ou ordem antecipada para cuidados médicos.

O que se nota como elemento categorial inderrogável é a declaração que visa a estabelecer ou repelir medidas interventivas de ordem médica para momento de eventual incapacitação, seja diretamente direcionada a um corpo clínico, seja indiretamente, apenas por uma simples atribuição da faculdade de agir em nome do paciente. No entanto, como elementos naturais - noutras palavras, não necessariamente presentes em todas as figuras de diretivas antecipadas -, há a outorga de poderes de representação, as disposições concernentes a tratamento já pré-determinadas pelo declarante e a própria ordem ou diretriz antecipada.

O elemento particular ou acidental, como foi possível adiantar noutras passagens, é a condição suspensiva ilustrativa de evento que gere a incapacitação do indivíduo, tornando-o tecnicamente incapaz de fato para externar conscientemente a sua vontade, momento em que se desencadeiam todos os efeitos confinados no objeto do negócio jurídico. São exemplos destes eventos o acidente que leve a vítima ao coma e o avançar da doença de Alzheimer, paulatinamente corroendo o discernimento do paciente, de maneira a obrigar parentes e médicos a observarem o que o enfermo outrora cristalizou em instrumento apropriado.

Progredindo-se, então, ao plano da validade, devem-se perscrutar as adjetivações aos elementos de existência, tarefa já empreendida no caso do objeto, porém pendente aos demais elementos. Quanto ao agente, o 
art. 104, I, do CC faz alusão à capacidade. De fato, o declarante deve estar na plenitude de suas faculdades mentais, gozando da capacidade de fato para que possa realizar esse negócio jurídico existencial.

Nesse contexto, indaga-se a necessidade de haver um laudo médico previamente à lavratura do instrumento das instruções prévias. Claro que este parecer servirá como um importante elemento de prova asseverando a sã consciência do paciente, ${ }^{57}$ de forma que, se as circunstâncias convergirem para uma lide judicial implicando nas pessoas próximas à vítima, a autoridade judicial certamente o considerará na formação do livre convencimento motivado, sem se permitir de antemão afirmar que essa prova refutará todos os outros elementos probatórios, consoante art. 479 do vigente CPC. Contudo, essa avaliação médica antecipada não pode jamais se tornar medida imprescindível para conferir validade à declaração, na medida em que, salvo prova em sentido oposto, é preferível presumir a plena capacidade do agente que, até o evento desencadeador, sempre gozou de total autonomia para a prática dos atos da vida civil.

Em relação à validade da forma, enquanto não houver norma jurídica pré-estabelecendo uma ou algumas formas para revestimento da declaração de vontade, entende-se que não cabe ao intérprete condicionar essa vestimenta jurídica a uma única e exclusiva configuração, preservando-se, por conseguinte, o princípio da liberdade de formas (art. 107 do CC), salvo regra em sentido contrário (art. 104, III, do CC).

Por fim, ainda se pergunta se no campo específico das diretivas antecipadas de vontade há a pertinência de introduzir um novo requisito de validade, consistente na chamada capacidade de consentimento, à luz do pensamento originariamente professado em Portugal por André Gonçalo Dias Pereira (2004), acolhido no Brasil por juristas que se dedicaram ao assunto (MARTINS-COSTA, 2009, p. 324; NANNI, 2011, p. 28-29).

Essa capacidade de consentir se vincula estritamente aos casos ligados ao desenvolvimento da personalidade e à disposição de direitos da personalidade, mais propriamente à autonomia privada para decidir questões relativas à saúde do declarante, em última análise autorizando-se ou restringindo-se a intervenção médica nos cuidados por ele desejados. De fato, se adotada uma acepção bastante delimitada de capacidade negocial, restrita rigorosamente a negócios patrimoniais - como já apontado na obra de Ana Prata -, essa elaboração teórica faz todo o sentido. De outro lado, se tratada a autonomia privada numa concepção ampla, com aptidão para abranger não só negócios patrimoniais, mas também extrapatrimoniais, não se atina a motivos fortes o bastante para sustentar a adição de outro requisito de validade. Em suma, parece que a justificação da capacidade de consentimento depende da terminologia e do recorte semântico empreendido por cada intérprete, optando-se, por ora, pela inserção da novel categoria jurídica na capacidade de fato.

\footnotetext{
${ }^{57}$ No caso do tabelionato de notas, quem afere a capacidade é o tabelião, porém na praxe é corriqueiro o pedido, pelo próprio delegatário, de apresentação de laudo médico que ateste o discernimento e a lucidez do usuário, ainda que o ordenamento revista a declaração do notário de fé pública no tocante aos fatos que narrar terem ocorrido à sua presença (art. 405 do NCPC).
} 
A despeito das divergências que se possam verificar, a relevância da categoria é inegável, tendo-se em mente importantes adeptos da vertente em comento, que recusam a adoção da capacidade negocial tradicional para lidar com problemas atinentes a bens da personalidade, tais como integridades física e psíquica, saúde de modo geral e vida. Transparecem, assim, na capacidade de consentimento, o esclarecimento e a consciência para a tomada de decisão sobre bens personalíssimos deparados com as ameaças, os perigos, as aflições e as privações que integram o catálogo de escolhas postas à disposição do paciente.

Nesse diapasão, quatro são os parâmetros casuísticos - no sentido de serem aferidos concretamente, caso a caso - da capacidade de consentimento, passando por: juízo axiológico do próprio paciente, capacidade de fazer uma prognose do curso causal-natural da enfermidade, discernimento necessário à escolha das possibilidades que lhe são oferecidas e capacidade de autodeterminar-se após receber subsídio informativo assegurador de decisão adequadamente fundamentada.

Independentemente de acrescentar-se mais um requisito de validade ligado ao elemento existencial extrínseco do agente (JUNQUEIRA DE AZEVEDO, op. cit., p. 42-3), o fato é que as ponderações por ele albergadas são de fundamental citação diante da investigação teórica de qualquer negócio jurídico extrapatrimonial, que, em virtude da sensibilidade dos valores colidentes, merecem amadurecida decisão por parte do indivíduo que antecipa suas instruções.

Por fim, preocupando-se com o armazenamento e organicidade das informações, observa-se que há países como Portugal e Espanha utilizando registro administrativo de testamento vital, o qual não tem a aptidão de tornar a declaração eficaz, tampouco de conferir-lhe publicidade registral stricto sensu, já que se trata de órgão de natureza puramente administrativa. No entanto, gozam de importante papel organizador de dados e garantidor de transparência, fornecendo informações sólidas a parentes e a profissionais da saúde que porventura tenham de atender o paciente autor de diretivas antecipadas, sem, decerto, menoscabar a preservação do sigilo de informações pessoais..$^{58}$

\section{O exame comparado}

Com o simples propósito de ilustrar brevemente o cenário internacional no tocante ao regime das diretivas antecipadas, comparando-o com a escassez normativa nacional, que demonstra certo descompasso brasileiro, não no plano da produção bibliográfica, já bastante difundida, mas sim com relação a uma disciplina legal stricto sensu clara e minuciosa.

\footnotetext{
${ }^{58}$ No Brasil, já há similar sistemática com os testamentos tradicionais de Direito das sucessões, conforme o Provimento n. ${ }^{\circ}$ 18/2012, do Conselho Nacional de Justiça (CNJ), que no art. 30 disciplina o Registro Central de Testamentos "On Line" (RCTO), módulo componente da Central Notarial de Serviços Eletrônicos Compartilhados (CENSEC), estabelecendo-se então o dever a todos os notários do Brasil de remeterem-lhe os testamentos que lavrarem em suas serventias.
} 
Iniciando-se esse panorama internacional pelos EUA, país onde o referido Luis Kutner ao final da década de 60 formulou o living will, teve-se a promulgação de diploma legal pouco mais de duas décadas depois do nascimento do instituto, em 1991, graças ao designado Patient Self-Determination Act, posteriormente se estendendo ao regramento dos estados da federação ainda na década de 90. Estudos empíricos demonstram que o PSDA foi importante para aumentar o número de pacientes que passaram a fazer uso das diretivas antecipadas, assim como as discussões gerais a respeito dos problemas relacionados ao fim da vida, porém o aumento não foi tão significativo se se atentar para o número de declarações em documentos escritos, ou para o diálogo entre médicos e pacientes sobre os documentos e questões terminais (EMANUEL, 1993, p. 619).

Sem dúvida, crucial para o aludido diploma foram os fatos de grande repercussão no país, mais especificamente o caso de Nancy Cruzan e do Doutor Morte (Jack Kevorkian), ambos discutidos por Dworkin em Life's dominion. ${ }^{59}$

Hoje, no entanto, o instituto já está tão popularizado no Direito norte-americano que, ao consultarem-se livrarias para aquisição de trabalhos a respeito do testamento biológico, encontram-se, na grande maioria delas, obras que se destinam a guiar leigos a realizar adequadamente um documento deste tipo.

Ao final da década de 90, na cidade de Oviedo, Espanha, foi firmada em 4 de abril de 1997 a Convenção para a Proteção dos Direitos do Homem e da Dignidade do Ser Humano face às Aplicações da Biologia e da Medicina pelo Conselho da Europa, cuja vigência internacional se iniciou a partir de $1^{\circ}$ de dezembro de 1999. No art. $9^{\circ}$, previu-se sinteticamente que será levada em consideração a vontade do paciente externada anteriormente à

\footnotetext{
${ }^{59}$ O caso Nancy Cruzan (USSC, Cruzan v. Director, DMH - 497 U.S. 261) diz respeito a jovem no Estado do Missouri que, aos vinte e cinco anos, em 1983, sofrera acidente de carro e, como consequência, entrou em estado de inconsciência permanente. Diante da irreversibilidade do quadro, tanto os pais como o marido da paciente pediram a retirada de aparelhos que faziam a nutrição e a hidratação assistida, medida que foi rejeitada pela instituição hospitalar sem o prévio comando judicial. A Suprema Corte do Estado do Missouri autorizou a interrupção, decisão posteriormente corroborada pela Suprema Corte dos EUA. O caso, no entanto, despertou intenso debate no país, já que entre a fatalidade e o falecimento de Nancy Cruzan se transcorreram quase oito anos. O outro caso igualmente polêmico foi o de Jack Kevorkian, apelidado de Doutor Morte, fervoroso defensor da eutanásia, que foi inclusive condenado pela Justiça norte-americana por homicídio em caso no qual assistira um paciente em procedimento de eutanásia. Após sair da prisão, o médico confessou haver auxiliado mais de 130 pessoas na prática da eutanásia, justificando, porém, que não as praticou visando terminar a vida dos seus pacientes, mas, sim, cessar o sofrimento dessas pessoas - conforme entrevista concedida por Kevorkian ao jornalista Anderson Cooper em 2010 no canal televisivo CNN. Disponível em: <https://www.youtube.com/watch?v=EQmyo6EvUY8>. Acesso em: 02 abr. 2016. Por último, não se esqueça do caso de Eluana Englaro, italiana que entrou em estado vegetativo por decorrência de acidente automobilístico, permanecendo nesta situação por dezessete anos, período no qual os pais e pessoas próximas à garota tentaram por diversas vezes na Justiça a autorização para desligamento das medidas que prolongavam artificialmente a vida da acidentada. Eluana Englaro faleceu em 2009, graças a sucessivos recursos interpostos pelo pai, finalmente interrompendo-se a nutrição artificial por força de acórdão da Corte de Apelação de Milão. Ainda que respaldado pelo comando jurisdicional, chegou-se a abrir inquérito contra Beppino Englaro, arquivado pela Procuradoria da República em Údine somente após um laudo pericial asseverar que os danos encefálicos oriundos do acidente eram anatomicamente irreversíveis (Eluana: il pm chiede l'archiviazione: 'Non fu omicidio volontario'. La Repubblica, 28 nov. 2009. Disponível em: <http://www.repubblica.it/2009/11/sezioni/cronaca/englaro/englaro/englaro.html>. Acesso em: 02 abr. 2016).
} 
intervenção médica quando ele não possa, no momento do atendimento, externar conscientemente sua vontade. ${ }^{60}$

Na Espanha, a Ley 41, de 14 de novembro de 2002, foi promulgada para disciplinar a autonomia do paciente e os direitos e as obrigações em matéria de informação e documentação clínica. O diploma tem a finalidade de albergar um número maior de matérias sanitárias, não se limitando evidentemente às diretivas antecipadas, que foram disciplinadas no art. 11, ${ }^{61} \mathrm{em}$ seu bojo dispondo não só as tradicionais diretivas, mas também o mandato duradouro.

Ademais, o Decreto Real n. ${ }^{\circ}$ 124, de 15 de fevereiro de 2007, institui o Registro Nacional de Instruções Prévias, ligado ao Ministério de Saúde e Consumo. Conforme o art. 2 do mesmo regulamento, por meio do registro se assegura a eficácia e o conhecimento no território espanhol das instruções prévias lavradas em conformidade com a legislação. Observa, ademais, a necessidade de o órgão responsável pelo registro administrativo tomar as providências para preservação do sigilo dos dados pessoais armazenados.

$\mathrm{Na}$ Itália, o caso de Eluana Englaro chamou a atenção da imprensa e dos políticos: apesar de o pai e as testemunhas próximas à jovem irem a juízo para afirmar que a garota thes havia previamente manifestado a repugnância à manutenção artificial da vida, manteve-se, em contrariedade às provas orais, uma menina de 21 anos de idade em estado vegetativo por 17 anos consecutivos.

Enquanto tramitava um projeto de lei no Senado que visava à disciplina da alimentação e hidratação artificiais, em 2009, a menina faleceu, fazendo com que os parlamentares alterassem a matéria do projeto para se adaptar ao testamento biológico e às demais questões ligadas ao fim da vida. No entanto, ainda persiste a ausência legal, haja vista a forte oposição social de origem católica no país. ${ }^{62}$ Isso, porém, não significa que o contingente de

\footnotetext{
${ }^{60}$ Artigo 9. Vontade anteriormente manifestada. A vontade anteriormente manifestada no tocante a uma intervenção médica por um paciente que, no momento da intervenção, não se encontre em condições de expressar a sua vontade, será tomada em conta.

${ }^{61}$ Artículo 11. Instrucciones previas. 1. Por el documento de instrucciones previas, una persona mayor de edad, capaz y libre, manifiesta anticipadamente su voluntad, con objeto de que ésta se cumpla en el momento en que llegue a situaciones en cuyas circunstancias no sea capaz de expresarlos personalmente, sobre los cuidados y el tratamiento de su salud o, una vez llegado el fallecimiento, sobre el destino de su cuerpo o de los órganos del mismo. El otorgante del documento puede designar, además, un representante para que, llegado el caso, sirva como interlocutor suyo con el médico o el equipo sanitario para procurar el cumplimiento de las instrucciones previas. 2. Cada servicio de salud regulará el procedimiento adecuado para que, llegado el caso, se garantice el cumplimiento de las instrucciones previas de cada persona, que deberán constar siempre por escrito. 3. No serán aplicadas las instrucciones previas contrarias al ordenamiento jurídico, a la «lex artis», ni las que no se correspondan con el supuesto de hecho que el interesado haya previsto en el momento de manifestarlas. En la historia clínica del paciente quedará constancia razonada de las anotaciones relacionadas con estas previsiones. 4. Las instrucciones previas podrán revocarse libremente en cualquier momento dejando constancia por escrito. 5. Con el fin de asegurar la eficacia en todo el territorio nacional de las instrucciones previas manifestadas por los pacientes y formalizadas de acuerdo con lo dispuesto en la legislación de las respectivas Comunidades Autónomas, se creará en el Ministerio de Sanidad y Consumo el Registro nacional de instrucciones previas que se regirá por las normas que reglamentariamente se determinen, previo acuerdo del Consejo Interterritorial del Sistema Nacional de Salud.

${ }^{62}$ Nesse sentido, é emblemática a frase do Cardeal da Igreja Católica Angelo Bagnasco, Presidente da Conferência Episcopal Italiana, que, em prolusão ao Conselho Permanente realizado entre 22 e 25 de setembro de 2008, em Roma, afirmou que embora fosse razoável evitar o insistente prolongamento da vida por formas inúteis, dever-se-ia tomar muito cuidado com formas
} 
pessoas favoráveis à regulamentação seja pequeno, tanto que já há a difusão de um aplicativo chamado The Last Wish, utilizável mediante rede social, que tem por fim publicar mensagem em perfil no caso de falecimento do usuário (PAPPAGALLO, 2008). ${ }^{63}$

Finalmente, em Portugal, há a Lei n. ํ 25, de 16 de julho de 2012, cujo sumário aponta a disciplina das diretivas antecipadas de vontade, a nomeação de procurador de cuidados de saúde e o Registro Nacional do Testamento Vital (RENTEV). Uma peculiaridade interessante do regime legal lusitano diz respeito ao prazo eficacial de cinco anos, a contar da assinatura, obrigando-se o RENTEV a informar o outorgante antes da expiração do prazo, com até 60 dias de antecedência em relação ao termo final ( $\left.\operatorname{art.} 77^{\circ}, 4\right)$.

Além disso, os portugueses tiveram o cuidado de disciplinar os limites ao objeto das diretivas antecipadas no copo do diploma legal em comento, incluindo-se neste rol a vedação às práticas que contrariem o ordenamento jurídico, as intervenções que levem deliberadamente à morte não natural e evitável e, por último, as situações em que a vontade não tenha sido exarada de maneira clara $\left(\operatorname{art} .5^{\circ}\right) \cdot{ }^{64}$

Por outro lado, houve tamanha intensificação da prática na Holanda que já há notícias de cidadãos cristãos portando carteiras que afirmam: "por favor, ressuscite-me", frase indicativa da preferência pela manutenção da vida a todo custo por parte do eventual acidentado, temeroso quanto à banalização ou má compreensão da ortotanásia (COOK, 2011).

Note-se, enfim, para arrematar esse exame comparado, a letargia legislativa brasileira em disciplinar o assunto mediante diploma nacional, que certamente não terá aprovação consensual no Congresso Nacional, tendo-se em mente os diversos grupos de interesses que legitimamente discutem seus oponentes pontos de vista em matérias sensíveis como essa. Contudo, como prenuncia a experiência estrangeira de normatização interna e externa - no âmbito de tratados multilaterais -, o Brasil não pode ficar à margem dessa tendência constatada em diversos países de base cultural latina e ascendência jurídica romano-germânica.

Muito embora oscilantes os modelos legais quanto aos limites da declaração, é indispensável um marco regulador que afaste dúvidas e incertezas, de modo a propiciar mais segurança tanto ao paciente, que ficará seguro de que sua vontade será respeitada, quanto aos médicos e respectivos corpos clínicos, que não se recearão de

\footnotetext{
\begin{tabular}{llllll}
\hline mascaradas de legitimar & D
\end{tabular} <http://www.chiesacattolica.it/pls/cci_new/bd_edit_doc.redir_doc?id_doc=13943\&id_ufficio=10\&id_allegato=5103\&url_r imando=/cci_new/documenti_cei/2008-09/24-16/ProlusioneCardBagnasco.doc $>$. Acesso em: 30 abr. 2016.

${ }^{63}$ A forte oposição ao testamento vital também foi percebida em 2010 pela circular editada por três ministros do governo italiano que o despia de qualquer eficácia jurídica, conforme noticiado por La Repubblica (Il governo blocca il biotestamento 'non validi i $\begin{array}{llllll}\text { registri dei } & \text { Comuni. } & 19 & \text { nov. } & 2010 . & \text { Disponível }\end{array}$ <http://www.repubblica.it/cronaca/2010/11/19/news/biotestamento_circolari-9290090>. Acesso em: 28 mar. 2016).

${ }^{64}$ No fundo, a confirmar o que se advertiu no tópico anterior, todas essas causas são perfeitamente resolvidas pela teoria geral do negócio jurídico, já que consistem, na respectiva ordem, em objeto ilícito (os dois primeiros casos) e em erro essencial ou em falha redacional que, por força da ambiguidade ou confusão, impede a intelecção por parte do médico.
} 
ulteriores responsabilizações nas esferas cível e administrativo-profissional decorrentes da hodierna lacuna legislativa.

\section{Existe morte digna no brasil?}

É chegada a hora de discutir e propor uma resolução ao cerne deste trabalho: há morte digna no Brasil, ou, por outras palavras, diante dessa ponderação valorativa desenhada no início de trabalho e da subsequente instrumentalização da liberdade individual por meio das diretivas antecipadas, é possível reconhecer a plena autonomia subjetiva para que uma pessoa disponha de sua vida em estágio terminal?

De fato, ao defrontar-se a vigente realidade normativa brasileira, é natural que surja a inquietação no sentido de indagar se seria possível reconhecer no país a efetividade da noção de morte digna, isto é, a absoluta liberdade do paciente para decidir sobre sua vida no futuro, quando não tiver condições de externar à vontade, principalmente em face da clara vedação à eutanásia.

Indubitavelmente, trata-se de questionamento muito complicado, pois tudo depende da posição e do quão longe se pretende defender a autonomia do paciente. ${ }^{65}$

Numa primeira abordagem, como mero operador do direito que não pode discutir os dogmas (normas jurídicas positivadas), parte-se da premissa de que a eutanásia é conduta tipificada criminalmente, mas nem por isso obstativa do exercício da liberdade de morrer dignamente, em harmonia com as balizas postas pela ordem jurídica, afinal, a própria autonomia privada não tem caráter irrefreável, sendo delimitada por normas de interesse público ou social.

Por outro lado, numa visão zetética (FERRAZ JUNIOR, op. cit., p. 21), poder-se-ia questionar a constitucionalidade da norma que criminaliza a eutanásia: seria ela compatível com a dignidade da pessoa humana e com a autonomia privada, nas bases outrora tratadas ${ }^{26}$ Deveras, a regra proibitiva (art. $121, \mathbb{\$} 1^{\circ}$, do

\footnotetext{
${ }^{65} \mathrm{Na}$ Itália, por exemplo, conforme a posição do publicista Lorenzo Chieffi (2012, p. 137-188), o projeto de lei à época posto em discussão na Câmara era demasiadamente restritivo à autonomia privada do paciente - sempre corretamente subsidiado das informações clínicas fornecidas pelo médico - e às formas de manifestação de sua vontade, implicando em última análise a inconstitucionalidade material, uma vez que o texto constitucional italiano tutela esse espaço de liberdade individual. Assim, o autor o classifica como paternalista e autoritário, pois impede um juízo de proporcionalidade pelo próprio enfermo, que poderia, por conseguinte, valer-se de testamento vital para documentar suas orientações. Ademais, a reforçar a defesa pela possibilidade de escolha do paciente nas diretivas antecipadas de vontade, de fundamental transcrição a crítica conclusiva de Chieffi à obstinação por um prolongamento artificial da vida em casos nos quais nitidamente se mantém o paciente sob uma situação existencial insuportável: "Nonostante gli incontestabili benefici che, in numerose circostanze, il progresso medico ha arrecato al benessere dell'individuo, allo stesso tempo l'impiego di queste sofisticate tecnologie per la rianimazione e il sostegno vitale, in grado di consentire il prolungamento dell'esistenza umana, dovrebbe allora esigere un 'supplemento di saggezza', al fine di non protrarre nel tempo i 'trattamenti quando non giovano più alla persona' per essersi trasformati in rimedi che, pur non configurando una forma di accanimento terapeutico, comunque vietato, costringano l'interessato ad una esistenza ritenuta insopportabile, assai distante da un immagine di vita giudicata accettabile".

${ }^{66}$ Veja-se, por exemplo, a discussão no Canadá sobre a eutanásia. Entende-se pertinente a menção ao país porque, em linhas gerais - isto é, sem descer individualmente a cada fundamento adotado pela Suprema Corte canadense -, o acórdão resultante do
} 
CP) nascida em 1940 não mais espelha o contexto sociocultural vivido no século XXI, sob a égide de uma Constituição regente de Estado Democrático de Direito, que teve como princípio fundante a dignidade da pessoa humana. ${ }^{67}$ Isso, contudo, não pode ser banalizado enquanto estiver vigente a aludida minorante penal. $\mathrm{O}$ legislador fez uma valoração, ponderou bens jurídicos, e, por tal motivo, deve-se respeitar a prevalência atribuída ao valor vida no caso da eutanásia, até que haja alteração neste cenário normativo por intermédio das vias jurídicas disponíveis, quais sejam o exercício do poder legiferante e o controle concentrado de constitucionalidade - neste segundo caso, um verdadeiro juízo de recepção da vetusta norma pela ordem constitucional fundada em 1988.

Em síntese, apesar de propugnar-se a tese de que a liberdade do paciente há de ser expandida com o intuito de possibilitar a opção pela eutanásia em contextos drásticos, nos quais realmente inexista esperança ao paciente, que ainda tem de lidar com situação de imenso sofrimento físico e psíquico - portanto, sob o enfoque normativo, declarando-se a não recepção da norma penalizante -, o ceticismo relativo à proibição da eutanásia no país não é forte o bastante para refutar a percepção de que existe hodiernamente a tutela da morte digna como um

precedente Carter v. Canada (Attorney General), com julgamento em 6 de fevereiro de 2015, afastou a tipicidade da conduta daquele que pratica a eutanásia, até então punido pelo Código Penal de maneira similar à prevista no Brasil. Assim, lá restou entendido que os médicos podem assistir os pacientes a abreviar a vida, contanto que estes estejam em situação penosa e irrecuperável. No entanto, numa espécie de modulação dos efeitos da decisão, a Suprema Corte canadense concedeu o prazo de 12 meses para que o parlamento produzisse as modificações legislativas necessárias à eliminação do tipo penal, além de autorizar que as cortes provincianas chancelassem os pedidos de eutanásia por paciente nas condições aludidas retro. Seguem trechos do acórdão que se consideram fundamentais: "The appeal should be allowed. Section 241 (b) and s. 14 of the Criminal Code unjustifiably infringe s. 7 of the Charter and are of no force or effect to the extent that they prohibit physician-assisted death for a competent adult person who (1) clearly consents to the termination of life and (2) has a grievous and irremediable medical condition (including an illness, disease or disability) that causes enduring suffering that is intolerable to the individual in the circumstances of his or her condition. The declaration of invalidity is suspended for 12 months. Special costs on a full indemnity basis are awarded against Canada throughout. The Attorney General of British Columbia will bear responsibility for 10 percent of the costs at trial on a full indemnity basis and will pay the costs associated with its presence at the appellate levels on a party-andparty basis. (...) Insofar as they prohibit physician-assisted dying for competent adults who seek such assistance as a result of a grievous and irremediable medical condition that causes enduring and intolerable suffering, ss. 241 (b) and 14 of the Criminal Code deprive these adults of their right to life, liberty and security of the person under s. 7 of the Charter. The right to life is engaged where the law or state action imposes death or an increased risk of death on a person, either directly or indirectly. Here, the prohibition deprives some individuals of life, as it has the effect of forcing some individuals to take their own lives prematurely, for fear that they would be incapable of doing so when they reached the point where suffering was intolerable. The rights to liberty and security of the person, which deal with concerns about autonomy and quality of life, are also engaged. An individual's response to a grievous and irremediable medical condition is a matter critical to their dignity and autonomy. The prohibition denies people in this situation the right to make decisions concerning their bodily integrity and medical care and thus trenches on their liberty. And by leaving them to endure intolerable suffering, it impinges on their security of the person". A decisão, porém, está longe de ser pacificamente aceita pela sociedade canadense, podendo-se mencionar a comunidade indígena, que afirma não pertencer à sua cultura a prática da eutanásia (COOK, 2016).

${ }^{67}$ Portanto, concorda-se com Ronald Dworkin (op. cit., p. 322), segundo o qual o testamento vital há de ser compreendido como um juízo do paciente acerca da vida que pretende levar - ou ter levado, se se estiver lendo as diretivas quando houver a necessidade de intervenção médica, porém sempre a examinando numa perspectiva integral, de forma a encarar o futuro como etapa que pode influir na natureza do todo. Nesse sentido, adverte que não cabe ao Estado, ou a qualquer julgador externo, impor uma única concepção generalizando que o final da vida deva se dar de uma maneira ou de outra (Ibid., p. 301). Por tal motivo, propugna que é relativa a ideia do que seja viver bem, dependendo do entendimento individual referente ao término da vida e dos interesses críticos considerados pessoalmente por cada pessoa. Com base nessas reflexões, as passagens salientadas convergem para o norteamericano encerrar a obra pregando a importância intrínseca e pessoal da vida humana. 
instituto abstratamente tutelado pelo Direito brasileiro. Dessa maneira, interpretam-se essas limitações como uma predileção axiológica do legislador infraconstitucional, que repercutem sobre a extensão do exercício da autonomia do enfermo, sem que isso, contudo, leve ao exagero de afirmar-se a lacuna de proteção à morte digna.

\section{CONCLUSÃO}

Neste trecho conclusivo, a intenção é a de retomar as principais ideias lançadas nas páginas precedentes, oportunizando-se, além disso, a reiteração do ponto de vista externado em relação aos limites impostos ao poder subjetivo de disposição da vida.

A começar pela ideia de dignidade humana, em que pesem esses empecilhos linguísticos, são louváveis as tentativas conceituais, que procuram, senão defini-la, ao menos lançar luzes sobre as principais ideias extraíveis da dignidade da pessoa humana. Por tais motivos, filiou-se neste trabalho às dimensões sugeridas por Ingo Sarlet, que destaca as facetas ontológica (atributo inerente ao homem), histórico-cultural (ideal que se conforma progressivamente no amadurecer do pensamento ocidental), negativa (criação de esfera de proteção ao indivíduo, instrumentalizada sobretudo pelos direitos políticos e pela liberdade jurídica), prestacional (reconhecimento de direitos sociais que exigem a atuação positiva do Estado), objetiva (estrutura jurídica normativo-principiológica), subjetiva (preceito do qual emanam direitos fundamentais) e ecológica (modernamente visto como direito difuso fundamental, de interesse das presentes e futuras gerações).

Superadas as árduas questões conceituais, a positivação, dessarte, não tem a aptidão de menosprezar a imensa construção antropológica subjacente à dignidade da pessoa humana, porém impõe ao exegeta o tratamento do instituto sob a estrutura normativa de princípio, cuja definição pode oscilar de autor para autor, mas requer fundamentalmente a visão de que se trata de preceito finalístico, ou mandamento de otimização, que deve ser efetivado na maior medida do possível, em face do exame das circunstâncias jurídicas e fáticas pertencentes ao caso concreto.

Por conseguinte, a estrutura de princípio conduz às indagações concernentes à supremacia da dignidade sobre qualquer outro valor do sistema jurídico pátrio. Ora, se se trata de princípio, de imediato vem à mente o atributo da relatividade dessa categoria, que não tem prevalência a priori, devendo-se, ao contrário, primeiramente sopesar os princípios em conflito para então estabelecer, em determinado caso concreto, a prevalência de um em detrimento de outro.

Logo, por essas palavras pretende-se enfatizar, assim como acontece com qualquer outro princípio fundamental, o atributo da relatividade ínsito à dignidade da pessoa humana.

Assentadas essas premissas, parte-se para o exame da autonomia privada, a qual, embora refutada por corrente doutrinal, pode ser vista, sim, por força da aptidão normogenética, como um desdobramento da 
dignidade da pessoa humana, mormente se investigadas as repisadas elaborações filosóficas produzidas em torno da expressão, ainda em âmbito pré e extrajurídico (critérios cronológico e científico, respectivamente), como nas frisadas obras de São Tomás e de Giovanni Pico.

Por consequência, numa leitura moderna da autonomia privada, embora se adira ao ponto de vista segundo o qual a essência dela alberga o direito subjetivo de propriedade e a capacidade negocial, não se veem óbices ao enxerto dos negócios jurídicos extrapatrimoniais sob o manto desta última, que hodiernamente, num ordenamento que se propõe a colocar a pessoa como centro das preocupações, e não mais o patrimônio, deve ter seu espectro semântico alargado para compreender negócios como as diretivas antecipadas de vontade.

Some-se a essa revitalização da autonomia privada a disponibilidade relativa dos direitos da personalidade, entendidos como projeções do homem merecedoras de tutela jurídica por uma das três vertentes: integridade física, integridade psíquica ou integridade moral. Sem dúvida, neste contexto inclui-se o direito à vida e as discussões sobre sua disposição. De maneira providencial, adjetiva-se esse poder de dispor como relativo porque é evidente que há limites impostos ao seu exercício, provenientes da ordem jurídica como um todo.

Isso, entretanto, parece não obstar a viabilização dessa disponibilidade mediante a confecção de instruções prévias, nas quais se orientem os tratamentos que o autor deseje, ou simplesmente queira evitar, caso ingresse em estado de incapacitação, verbi gratia, por ingressar em coma, ou em estado vegetativo permanente, ou por se acometer de doença incurável e irreversível com progressiva perda do discernimento.

Nesse diapasão, parece que as barreiras à liberdade individual devem ceder perante a vontade do paciente de praticar a eutanásia, não, é claro, de maneira indiscriminada, mas em hipóteses muito específicas, nas quais tamanho sofrimento, ou a mais absoluta irreversibilidade fática da situação do e não possibilite de forma alguma, num juízo de proporcionalidade, reputar minimamente razoável conferir prevalência à mantença da vida contra o intento de seu próprio titular. Obviamente, referida asserção não implica a intenção de banalizar a eutanásia, muito pelo contrário, entende-se que o melhor seria uma delimitação de hipóteses pelo próprio legislador - em que pese a inegável falibilidade desse método -, com a finalidade de reduzir ao máximo a margem de situações concretas subsumíveis à autorização para a prática do ato de definitiva abreviação da morte.

Como se pode antever pelas discussões retomadas nestas considerações finais, os maiores problemas ligados às diretivas antecipadas se atêm: à delimitação do objeto lícito - passando principalmente pela vedação à eutanásia -, ao balizamento da forma válida, à delimitação temporal da eficácia e à criação de um órgão administrativo registral que permita congregar todas as diretivas antecipadas de vontade numa única base de dados.

Ademais, a formulação da chamada capacidade de consentimento parece ser de propícia introjeção na capacidade de fato, passando a configurar mais uma dimensão desta última nos casos específicos de diretivas 
antecipadas de vontade, com o intuito de examinar acuradamente o discernimento do declarante em pontos cruciais como o juízo valorativo, a prognose do desdobramento natural da enfermidade, o aclaramento quanto ao leque de escolhas posto à sua disposição e o potencial para se autodeterminar municiado das informações médicas necessárias.

Por fim, não há por que rejeitar a existência, na ordem jurídica brasileira, do ideal que se consubstancia na expressão "morte digna", na medida em que, não obstante proibida a eutanásia, há largo espaço às determinações abrangentes da distanásia e da ortotanásia, sempre em respeito à vontade declarada prospectivamente, mas externada ainda em momento de absoluta lucidez do paciente.

Indo-se além dessa conclusão eminentemente dogmática, que não questiona os pontos de partida fincados na vigente ordem jurídica, pode-se argumentar, com fulcro nos fundamentos expostos no decorrer deste trabalho, que os pilares da dignidade da pessoa humana e da autonomia privada devem servir de amparo constitucional à permissão da eutanásia, contudo precisamente delimitadas para que não ocorra a banalização do instituto rumo a uma repugnante instigação a práticas suicidas. Não é esta a finalidade para qual a eutanásia foi pensada, mas, ao revés, para trazer alguma solução digna ao paciente que, numa avaliação totalizante da vida, não vê mais sentido em sofrer tanto, ou não projeta mais esperanças por se encontrar em quadro clínico de total incapacidade, com duração indefinida e sem a menor expectativa de reversão. Daí pensar-se como saída útil e eficiente ao enfrentamento do problema a preparação de um testamento vital no qual se cristalizam esses desejos de maneira antecipada, enquanto o paciente ainda está na plenitude de suas aptidões psicofísicas.

\title{
DIGNITY AND AUTONOMY: THE DOGMATIC BRIDGE FOR THE LIVING WILL
}

\begin{abstract}
The present paper has the goal to examine the living will as an autonomous negotiating category from the principles of the dignity of the human person and the private autonomy. It is opted, for this purpose, for dialectical and deductive methodologies, thus confronting the thought of authors that have engaged upon the theme and performing inferences from the generic historical-philosophical premises outlined in the first sections of the work, with the complement of some judicial decisions. Therefore, it is understood that the living will has the nature of immaterial, unilateral and strictly personal legal transaction, with the object turned to the discipline of the medical interventions in a future moment, anticipating then the patient's desire or refusal to being kept artificially alive, or to receive certain treatment. The form has to be free, except for future legal disposition, and the agent has to enjoy the capacity of consent, implying specific discernment for the act. At the end, it is concluded that is necessary to admit the euthanasia in hypotheses strictly defined in the law, without meaning that the current prohibition is deterrent for the present recognition of the dignified death in Brazil.
\end{abstract}

Keywords: Dignity of the Human Person; Private Autonomy; Personality Rights; Living Will; Dignified Death. 


\section{REFERENCIAS BIBLIOGRÁFICAS}

AGUAS, Jove Jim S. "The notions of the human person and human dignity in Aquinas and Wojtyla". Kritique, v. 3, n. 1, p. 40-60, jun. 2009.

ALEXY, Robert. Teoria dos direitos fundamentais. Tradução de Virgílio Afonso da Silva. São Paulo: Malheiros, $2008.669 \mathrm{p}$.

ALVES, Cristiane Avancini. "Linguagem, Diretivas Antecipadas de Vontade e Testamento Vital: uma interface nacional e internacional". Revista Bioethikos - Centro Universitário São Camilo, v. 7, n. 3, p. 259-270, jul. /set. 2013.

AMARAL, Francisco. Direito civil: introdução. 7. ed. Rio de Janeiro: Renovar, 2008. 714 p.

ANDORNO, Roberto. "Regulating advance directives at the Council of Europe". In: NEGRI, Stefania (Org.). Self-determination, dignity and end-of-life care. Regulating Advance Directives in National and International Law. Series: Queen Mary Studies in International Law. Leiden: Brill Academic Publishers, p. 73-85, 2012.

AQUINO, São Tomás de. Summa Theologica: Complete American Edition. Tradução dos Padres da Ordem Dominicana Inglesa. Coyote Canyon Press. Disponível em: <https://ia600206.us.archive.org/31/items/SummaTheologicaCompleteUnabridgedThomasAquinas/Summa \%20Theologica\%20\%28Complete\%20\&\%20Unabridged\%29\%20-\%20Thomas\%20Aquinas.PDF>. Acesso em: 12 mar. 2016.

AVILA, Humberto. Teoria dos princípios: da definição à aplicação dos princípios jurídicos. 12. ed. São Paulo: Malheiros, $2011.206 \mathrm{p}$.

BARROSO, Luís Roberto. "'Aqui, lá e em todo lugar': a dignidade humana no direito contemporâneo e no discurso transnacional". Tradução de Humberto Laport de Mello. Revista dos Tribunais, São Paulo, v. 101, n. 919 , p. 127-196, maio 2012.

BETTI, Emílio. Teoria geral do negócio jurídico. Tradução de Fernando de Miranda. Coimbra: Coimbra, 1969. III t.

BÍBLIA. Português. Bíblia sagrada. Tradução de João Ferreira de Almeida. LCC Publicações Eletrônicas. Disponível em: <http://www.ebooksbrasil.org/adobeebook/biblia.pdf>. Acesso em: 28 mar. 2016.

BONAVIDES, Paulo. Curso de direito constitucional. 25. ed. São Paulo: Malheiros, 2010.835 p.

BORGES, Roxana Cardoso Brasileiro. Disponibilidade dos direitos de personalidade e autonomia privada. 2003. Tese (Doutorado em Direito das Relações Sociais) - Pontifícia Universidade Católica de São Paulo, São Paulo, 2003. $257 \mathrm{f}$.

CARVALHO, Aurora Tomazini de. Curso de teoria geral do direito. 4. ed. São Paulo: Noeses, 2014. 831 p.

CARVALHO, Paulo de Barros. Direito tributário, linguagem e método. 4. ed. São Paulo: Noeses, 2011.998 p. Constructivismo lógico-semântico. São Paulo: Noeses, 2014. Iv. 415 p. 
CHIEFFI, Lorenzo. "Il diritto all'autodeterminazione del malato terminale: tecniche di interpretazione di un valore costituzionale". Revista da Academia Paulista de Direito, São Paulo, n. 4, p. 137-188, jul. / dez. 2012.

CÍCERO, Marco Túlio. De officiis. Tradução de Walter Miller. London: William Heinemann; New York: Putnam's sons, $1913.456 \mathrm{p}$.

DADALTO, Luciana. "Aspectos registrais das diretivas antecipadas de vontade". Civilista.com: revista eletrônica de direito civil, v. 2, n. 4, 2013.

DE CUPIS, Adriano. Os direitos da personalidade. Tradução de Afonso Celso Furtado Rezende. Campinas: Romana, 2004.363 p.

DONNINI, Rogério. Responsabilidade civil na pós-modernidade: felicidade, proteção, enriquecimento com causa e tempo perdido. Porto Alegre: Fabris, 2015. 179 p

Responsabilidade civil pós-contratual. 3. ed. São Paulo: Saraiva, 2011.247 p.

DWORKIN, Ronald. Domínio da vida: aborto, eutanásia e liberdades individuais. Tradução de Jefferson Luiz Camargo. 2. ed. São Paulo: Martins Fontes, 2009.384 p.

Levando os direitos a sério. 2. ed. Tradução de Nelson Boeira. São Paulo: Martins Fontes, 2007. 568 p.

EMANUEL, Ezekiel J. et al. "How well is the patient self-determination act working? An early assessment". The American Journal of Medicine, New York, v. 95, n. 6, p. 619-628, dez. 1993.

ENGISCH, Karl. Introdução ao pensamento jurídico. Tradução de J. Baptista Machado. 7. ed. Lisboa: Calouste Gulbenkian, 1996.393 p.

FACHIN, Luiz Edson (Coord.). Repensando fundamentos do direito civil contemporâneo. Rio de Janeiro: Renovar, 1998.352 p.

PIANOVSKI, Carlos Eduardo. A dignidade da pessoa humana no Direito contemporâneo: uma contribuição à crítica da raiz dogmática do neopositivismo constitucionalista. Disponível em: <http://www.anima-opet.com.br/pdf/anima5-Conselheiros/Luiz-Edson-Fachin.pdf>. Acesso em: 27 mar. 2016.

FERRAZ JUNIOR, Tercio Sampaio. Introdução ao estudo do direito: técnica, decisão, dominação. 6. ed. São Paulo: Atlas, 2008.346 p.

FRANÇA, RUBENS LIMONGI. Manual de direito civil. 4. ed. São Paulo: Revista dos Tribunais, 1980. 4 v.

GARNER, Bryan A. (Org.). Black’s Law Dictionary.9. ed. Saint Paul: West, 2009. 1920 p.

HESSEN, Johannes. Filosofia dos valores. Tradução de L. Cabral de Moncada. São Paulo: Saraiva, 1946. 344 p.

HOUAISS, Antônio. Novo dicionário eletrônico Houaiss da língua portuguesa. Rio de Janeiro: Objetiva, 2009.

JUNQUEIRA DE AZEVEDO, Antonio. Caracterização jurídica da dignidade da pessoa humana. Revista da Faculdade de Direito da Universidade de São Paulo, São Paulo, v. 97, p. 107-125, 2002.

Negócio jurídico: existência, validade e eficácia. 4. ed. São Paulo: Saraiva, 2002. 172 p. 
KANT, Immanuel. Fundamentos da metafísica dos costumes. Tradução de Lourival de Queiroz Henkel. Rio de Janeiro: Edições de Ouro, 1967.150 p.

KASER, Max. Direito privado romano. Tradução de Samuel Rodrigues e Ferdinand Hämmerle. Lisboa: Calouste Gulbenkian, $1999.522 \mathrm{p}$.

LAFER, Celso. A reconstrução dos direitos humanos: um diálogo com o pensamento de Hannah Arendt. São Paulo: Companhia das letras, $1988.406 \mathrm{p}$.

LARENZ, Karl. Derecho civil: parte general. Tradução e notas de Miguel Izquierdo e Macías-Picavea. Madrid: EDERSA, 1978. $872 \mathrm{p}$.

MARTINS-COSTA, Judith; MÖLLER, Letícia Ludwig (Org.). Bioética e responsabilidade. Rio de Janeiro: Forense, $2009.445 \mathrm{p}$.

MELLO, Marcos Bernardes de. Teoria do fato jurídico - plano da existência. 15. ed. São Paulo: Saraiva, 2008. 294 p.

MOREIRA ALVES, José Carlos. Direito romano. 3. ed. Rio de Janeiro: Forense, 1980. 2 v.

MUÑOZ CONDE, Francisco. Edmund Mezger e o Direito Penal de seu tempo: estudos sobre Direitos Penal no nacional-socialismo. Rio de Janeiro: Lumen Juris, 2005. 282 p.

NANNI, Giovanni Ettore. A capacidade para consentir: uma nova espécie de capacidade negocial. Letrado: Informativo do Instituto dos Advogados de São Paulo, n. 96, p. 28-29, set. / out. 2011.

OLIVEIRA, Oris de. "Contribuição de Francisco de Vitoria ao Direito Internacional Público no de 'Indis Recenter Inventis, Relectio Prior'". Revista da Faculdade de Direito da Universidade de São Paulo, São Paulo, v. 68, n. 2, p. 361-384, 1973.

PEREIRA, André Gonçalo Dias. O consentimento informado na relação médico-paciente - estudo de direito civil. Coimbra: Coimbra Editora, 2004.700 p.

PICO DELLA MIRANDOLA, Giovanni. Discurso sobre a dignidade do homem. Tradução de Maria de Lourdes Sirgado Ganho. Lisboa: Edições 70, 2006. 117 p.

PONTES DE MIRANDA, Francisco Cavalcanti. Tratado de direito privado. São Paulo: Revista dos Tribunais, $2012.60 \mathrm{t}$.

PRATA, Ana. A tutela constitucional da autonomia privada. Coimbra: Almedina, 2016.216 p.

PUFENDORF, Samuel. Le Droit de la nature et des gens: ou systeme general, des principes les plus importants de la morale, de la jurisprudence, et de la politique. Tradução de Jean Barbeyrac. 5. ed. Amsterdam: Pierre de Coup, 1734, It.

REALE, Miguel. Paradigmas da cultura contemporânea. São Paulo: Saraiva, 1996.143 p.

Os direitos da personalidade. Disponível em: <http://www.miguelreale.com.br/artigos/dirpers.htm>. Acesso em: 04 mar. 2016. 
ROCHA, Cármen Lúcia Antunes. O princípio da dignidade da pessoa humana e a exclusão social. Disponível em: <http://egov.ufsc.br/portal/sites/default/files/anexos/32229-38415-1-PB.pdf>. Acesso em: 28 mar. 2016.

SAASTAMOINEN, Kari. Pufendorf on natural equality, human dignity, and self-esteem. Journal of the History of Ideas, University of Pennsylvania, v. 71, n. 1, p. 39-62, jan. 2010.

SALGADO, Fabiana Cristhina Almeida Probst. As diretivas antecipadas de vontade sob o enfoque do negócio jurídico. 2014. Dissertação (Mestrado em Direito Civil) - Pontifícia Universidade Católica de São Paulo. São Paulo, 2014.280 p.

SANTOS, Moacyr Amaral. Primeiras linhas de direito processual civil. 27. ed. São Paulo: Saraiva, 2011.3 v.;

SARLET, Ingo Wolfgang. Dignidade da pessoa humana e direitos fundamentais na Constituição Federal de 1988. 9. ed. Porto Alegre: Livraria do Advogado, 2012. 192 p.

SILVA, Virgílio Afonso da. "O proporcional e o razoável". Revista dos Tribunais, São Paulo, v. 91, n. 798, p. 23-50, abr. 2002.

SOUSA, Rabindranath Valentino Aleixo Capelo de. Direito geral de personalidade. Coimbra: Coimbra, 1995. $703 \mathrm{p}$.

TEPEDINO, Gustavo (Coord.). A Parte Geral do Novo Código Civil: Estudos na perspectiva civilconstitucional. Rio de Janeiro: Renovar, 2002. 458 p.

Temas de direito civil. 2. ed. Rio de Janeiro: Renovar, 2001.521 p.

VIEHWEG, Theodor. Topica y jurisprudencia. Tradução de Luis Díez-Picazo Ponce de Leon. Madrid: Taurus, 1964. $143 \mathrm{p}$.

Trabalho enviado em 27 de junho de 2016.

Aceito em 31 de agosto de 2016. 